\title{
Multi-level biological responses in Ucides cordatus (Linnaeus, 1763) (Brachyura, Ucididae) as indicators of conservation status in mangrove areas from the western atlantic
}

\author{
Luis Felipe de Almeida Duarte ${ }^{\mathrm{a}, *}$, Caroline Araújo de Souza ${ }^{\mathrm{a}}$, Caio Rodrigues Nobre ${ }^{\mathrm{b}}$, \\ Camilo Dias Seabra Pereira ${ }^{c}$, Marcelo Antonio Amaro Pinheiro ${ }^{a}$ \\ ${ }^{a}$ UNESP - Univ Estadual Paulista, Instituto de Biociências (IB), Campus do Litoral Paulista (CLP), Laboratório de Biologia de Crustáceos/CRUSTA, Praça Infante \\ Dom Henrique, s/n, Par - Grupo de Pesquisa em Biologia Laboratório de Biologia de Crustáceos-Praça, Infante D. Henrique, Campus Experimental do Litoral \\ Paulista (CLP), s/n, Parque Bitaru, 11330-900 São Vicente, São Paulo, Brazil \\ ${ }^{\mathrm{b}}$ UNISANTA - Univ Santa Cecília, Laboratório de Ecotoxicologia, Oswaldo Cruz 266, 11045-907 Santos, SP, Brazi \\ ' UNIFESP - Univ Federal de São Paulo, Departamento de Ciências do Mar, Campus Baixada Santista, Avenida Almirante Saldanha da Gama 89, Ponta da \\ Praia, 11030400 Santos, SP, Brasil
}

\section{A R T I C L E I N F O}

\section{Article history:}

Received 19 April 2016

Received in revised form

12 July 2016

Accepted 13 July 2016

Available online 22 July 2016

Keywords:

Environmental safety

Cytotoxicity

Density

Genotoxicity

Mangrove

Ucides cordatus

\begin{abstract}
A B S T R A C T
There is a global lack of knowledge on tropical ecotoxicology, particularly in terms of mangrove areas. These areas often serve as nurseries or homes for several animal species, including Ucides cordatus (the uçá crab). This species is widely distributed, is part of the diet of human coastal communities, and is considered to be a sentinel species due to its sensitivity to toxic xenobiotics in natural environments. Sublethal damages to benthic populations reveal pre-pathological conditions, but discussions of the implications are scarce in the literature. In Brazil, the state of São Paulo offers an interesting scenario for ecotoxicology and population studies: it is easy to distinguish between mangroves that are well preserved and those which are significantly impacted by human activity. The objectives of this study were to provide the normal baseline values for the frequency of Micronucleated cells (MN\%o) and for neutral red retention time (NRRT) in $U$. cordatus at pristine locations, as well to indicate the conservation status of different mangrove areas using a multi-level biological response approach in which these biomarkers and population indicators (condition factor and crab density) are applied in relation to environmental quality indicators (determined via information in the literature and solid waste volume). A mangrove area with no effects of impact (areas of reference or pristine areas) presented a mean value of $\mathrm{MN} \% 0<3$ and NRRT $>120 \mathrm{~min}$, values which were assumed as baseline values representing genetic and physiological normality. A significant correlation was found between NRRT and MN, with both showing similar and effective results for distinguishing between different mangrove areas according to conservation status. Furthermore, crab density was lower in more impacted mangrove areas, a finding which also reflects the effects of sublethal damage; this finding was not determined by condition factor measurements. Multi-level biological responses were able to reflect the conservation status of the mangrove areas studied using information on guideline values of MN\%o, NRRT, and density of the uçá crab in order to categorize three levels of human impacts in mangrove areas: PNI (probable null impact); PLI (probable low impact); and PHI (probable high impact). Results confirm the success of $U$. cordatus species' multilevel biological responses in diagnosing threats to mangrove areas. Therefore, this species represents an effective tool in studies on mangrove conservation statuses in the Western Atlantic.
\end{abstract}

(c) 2016 Elsevier Inc. All rights reserved.

\section{Introduction}

Although tropical ecosystems house $75 \%$ of the world's

\footnotetext{
* Corresponding author.

E-mail addresses: duarte.mepi@gmail.com (L.F.d.A. Duarte) carol.souza.bio@gmail.com (C.A.d. Souza), caio.biomar@gmail.com (C.R. Nobre), camilo.seabra@unifesp.br (C.D.S. Pereira), pinheiro@clp.unesp.br (M.A.A. Pinheiro).
}

biodiversity and generate approximately $60 \%$ of the primary productivity of the planet, ecotoxicological studies have been conducted almost exclusively in temperate ecosystems (Peters et al., 1997; Lacher and Goldstein, 1997; Sueitt et al., 2015). Such limited knowledge contrasts with current increasing human impacts in the tropics, impacts which are generally the result of unsustainable activities and the release of xenobiotics into water bodies. These activities ultimately have negative effects on the aquatic 
biota (Peters et al., 1997; Harford et al., 2015).

Different approaches, which consider information ranging from data at the population-community level to sentinel species' sublethal responses, are the current basis for most biomonitoring programs (Marine Strategy Framework Directive EU - MSFD, 2008/ 56/EC). Short-term responses among lower levels of biological organization have been used to detect the first signs of impairment caused by xenobiotics (Amiard-Triquet et al., 2013; Pereira et al., 2014). These responses have generally been referred to as "biomarkers," which are defined herein as genetic, biochemical, cellular, physiological, or behavioral variations that can be measured in tissue or body fluid samples or at the level of the whole organism and which provide evidence of exposure to and/or effects of one or more chemical pollutants and/or radiations (Depledge et al., 1993).

Genetic and physiological changes are therefore of particular importance, since they are conspicuous in organisms that inhabit impacted areas (Adams, 1990; Dailianis et al., 2003; Otomo and Reinecke, 2010; Amiard-Triquet et al., 2013; Toufexia et al., 2013). Because of their effectiveness and ecological relevance (Bonassi et al., 2000; Dailianis et al., 2003; Neri et al., 2003), two biomarker assays are widely used. The first is the micronucleus test (MN\%o), which quantifies the frequency of micronucleated cells and which measures genotoxicity. Genotoxicity is higher in more highly impacted areas (Brunetti et al., 1988; Burgeot et al., 1995; Collier et al., 2013; Pinheiro et al., 2013). The second is the neutral red retention time (NRRT) assay, which evaluates lysosomal membrane stability as a diagnostic biomarker of individual health status (Buratti et al., 2012, Ospar, 2013).

Genetic and physiological changes are considered pre-pathological indicators (Tsarpali and Dailianis, 2012) that can detect biological dysfunction in response to a stressor before population problems occur (Amiard-Triquet et al., 2013). As determined by Adams, (1990) and by Fishelson et al. (1999), such sublethal damages may have more serious effects, such as increases in disease, changes to mortality rates, and population decline. According to these authors, other parameters found at higher levels of biological organization, such as at the population level, may also be relevant bioindicators of environmental impact and quality (Bruner et al., 2001; Barrilli et al., 2015). Therefore, Fulton's condition factor $(\mathrm{K})$ would be a relevant population parameter in these assessments: it can quantify "well-being" as a ratio of size to individual weight (Lima-Junior et al., 2002), with higher values indicating better environmental quality (Viana et al., 2014; Barrilli et al., 2015). Similarly, density is a parameter that can be reduced by contaminants, as seen among crustaceans (Krebs and Valiela, 1974; Krebs and Burns, 1977), although the reverse effect can also occur, leading to an increase in density due the tolerance of contaminants and their indirect effects on the environment (Cannicci et al., 2009).

There is limited knowledge available on links between sublethal damages seen in the lower levels of biological organization and those seen in higher levels (at the population or community level), particularly when a multi-level approach is considered. However, in order for the biological model to be effective, it must consider a species that is both important to the ecosystem and sensitive enough to reveal early environmental disturbances (Beltrame et al., 2010, 2011; Pereira et al., 2012, 2014). Thus, Pinheiro et al. (2012) describe characteristics of the uçá crab (Ucides cordatus) that reflect its importance as a sentinel species in mangroves in the Western Atlantic: endemism and reduced mobility, bioturbation of sediments, feeding on leaves and sediments (deposit feeding); reduced growth, a relatively long lifespan, higher abundance, and increased ease of capture. The uçá crab accumulates contaminants in its tissues; there is a high correlation between this bioaccumulation and the genetic impacts observed (Pinheiro et al., 2012, 2013). As a result, these xenobiotics are magnified by the trophic chain of the mangrove (Fiscarelli and Pinheiro, 2002). This species also has a close relationship with three environmental compartments of mangroves with which it interacts and where it absorbs pollutants: (1) water, via contact, ingestion, the respiration process, and metabolite excretion; (2) sediment, via contact when digging burrows and mud feeding; and (3) trees, through their feeding on the senescent leaves and seedlings (Fiscarelli and Pinheiro, 2002; Pinheiro et al., 2013; Christofoletti et al., 2013).

A multi-level biological response approach must include not only the most ideal biological model - the area selected for study must also present a wide regional environmental impact gradient so that the investigation will be more effective and meaningful. Therefore, it is important to highlight the high anthropic impact observed in southeastern Brazil, particularly in coastal areas. However, pristine mangroves also exist and are represented by protected areas (Cetesb, 2001, 2007). It is, therefore, a contrasting scenario that has been mentioned and studied by several authors (Silva et al., 2002; Abessa and Ambrozevicius, 2008; Cordeiro and Costa, 2010; Martins et al., 2011; Pereira et al., 2011; Torres et al., 2012; Pinheiro et al., 2008, 2012, 2013).

Given both the contamination gradient of the mangroves in the region and the possible biological responses at the cellular, physiological, and population levels of a sentinel species (U. cordatus), this study aims to: (1) provide normal baseline values for the micronucleated cell frequency (MN \%o) and neutral red retention time (NRRT) in U. cordatus at pristine locations; and (2) perform a multi-level assessment using this species as a biological model by analyzing the effectiveness and ecological relevance of two biomarkers (genetic via MN \%o and physiological via NRRT), their correlation with population parameters (condition factor and density), and their interactions with the conservation status of different mangrove areas (determined via information from the literature and solid waste volume). The validation of this multilevel approach will allow for the conservation statuses of the mangroves to be categorized without the need for contaminant quantification or qualification. High costs are therefore avoided, which will provide more opportunities for diagnosing this ecosystem's conservation status.

\section{Materials and methods}

\subsection{Mangrove areas studied and their conservation statuses}

The coast of São Paulo State in Brazil is frequently divided into three sections referred to as the northern coast, the central coast, and the southern coast. These sections are distinguished by their coastal plain areas $\left(6000 \mathrm{~km}^{2}, 3200 \mathrm{~km}^{2}\right.$, and $7800 \mathrm{~km}^{2}$, respectively) (Gouveia, 2012), by the extent of river basins $(194,800$ ha, 281,800 ha, and 1,706,800 ha, respectively; see BRASIL (2006)), and by the extent of mangroves (central: 8858 ha; southern: 15,193 ha; see Cunha-Lignon et al. (2011a, 2011b) and Cunha-Lignon (2014)). The present study considered mangroves from only the central coast ( $8858 \mathrm{ha}$ ) and the southern coast (15,193 ha), which represent the vast majority of the state's mangrove area (99\%). These sections also have a history of human occupation and impact dating back to the $1500 \mathrm{~s}$ when the first Brazilian city (São Vicente) was founded on the central coast of the state (CunhaLignon et al., 2011b). Six mangrove areas have been established (Fig. 1), three of which are located on the central coast (Bertioga, or BET, Cubatão, or CUB, and São Vicente, or SAV) and the other three which are located on the southern coast (Iguape, or IGU; Cananéia, 


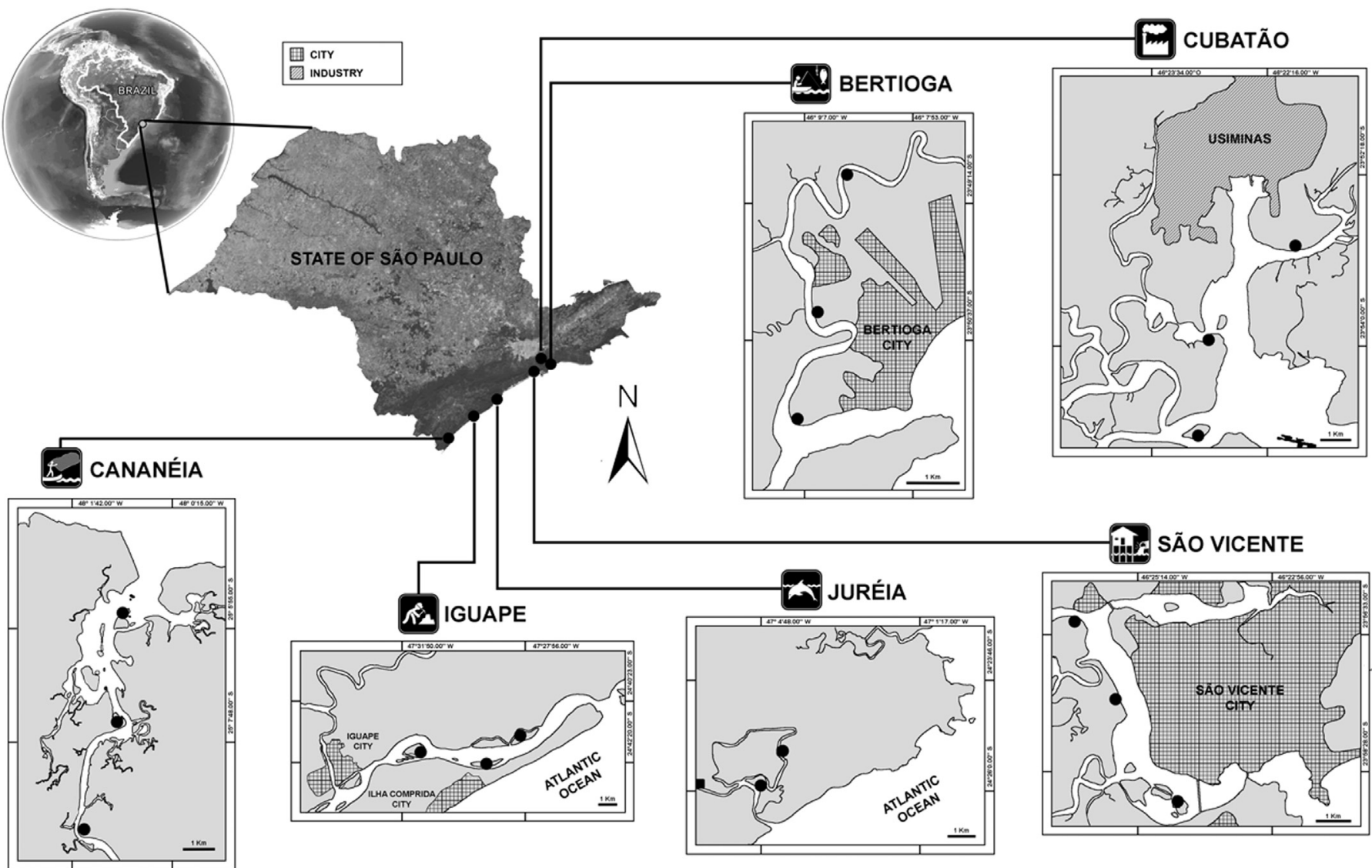

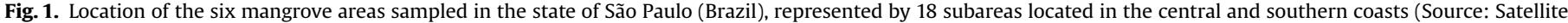
images from Google Earth ${ }^{\mathbb{R}}$ redesigned by Gustavo Pinheiro).

or CAN, and Juréia, or JUR, the latter of which is an ecological station). Each mangrove area includes three subareas (replicas) that are similar in tree composition ( $>50 \%$ Rhizophora mangle), vegetation structure (tree height $>5 \mathrm{~m}$ and diameter at breast height $>10 \mathrm{~cm}$ ), height of flooding by tides $(>30 \mathrm{~cm})$ and productivity (leaves available on the sediment $>2 \mathrm{~g} \mathrm{~m}^{-2}$ ). However, the six areas have experienced different types of human occupation and impacts, and different contamination levels. Each area has been characterized according to relevant parameters (see Table 1) and based on a review of the main pollutants recorded at concentrations above legally permitted levels for brackish water (Environment Canada, 1999a) and sediment (Environment Canada 1999b, FDEP 1994).

Located on the central coast of São Paulo, the Bertioga Estuary (BET) receives domestic untreated sewage and effluents from a public garbage dump as its main source of pollution. Even so, the estuary is used for ecotourism and sport fishing, including uçá crab fishing (Eichler et al., 2006). Cubatão (CUB) is considered one of the most polluted regions in the world; in recent years, it has become the most important Brazilian industrial hub, formed by 23 industrial complexes, 111 factories, and more than 300 pollution sources. Home to the largest port in Latin America, it also experiences large vessel transit in which several types of chemicals are imported and exported (Pinheiro et al., 2012, 2013). Located within the same estuarine complex is São Vicente (SAV). This area is known for its substantial human activity, low GDP, illegal slums located within estuarine regions, and a lack of wastewater treatment and solid waste collection (Cetesb, 2007; Kirschbaum et al., 2009; Cordeiro and Costa, 2010), the latter of which is intensified by 11 industrial sources of pollution and the long-standing illegal deposition of organochlorine compounds such as pentachlorophenol (PCP) into the environment. These three areas therefore have a history of more substantial human impact, with records of contamination by various xenobiotics, including metals (Azevedo et al., 2009; Pinheiro et al., 2012, 2013) and organochlorines (Martins et al., 2011). As a result, some sublethal damage has been observed in the local biota, including genetic changes reflected by an increase in micronucleus frequency and alterations in the cell nucleus. These changes have been confirmed in fishes, crabs, and mollusks (Kirschbaum et al., 2009; Caricato et al., 2010; Hagger et al., 2010; Dissanayake et al., 2011; Pinheiro et al., 2013).

The mangrove areas on the southern coast of São Paulo are approximately $80-200 \mathrm{~km}$ away from the mangrove areas on the central coast. The southern coast is comprised of estuaries with more conserved areas, though some of these areas have already exhibited effects of indirect anthropogenic influence. The Estuarine System that includes Cananéia, Iguape, and Juréia is located within a single environmental protection area (EPA) that also includes the entire state of Paraná. Together, these land masses form the Lagamar Complex, one of the largest estuarine complexes in Brazil. It covers $3287 \mathrm{~km}^{2}$ and includes other interconnected basins (ISA, 1998). Located in the northeastern most portion of this complex is the area known as Iguape (IGU), which until the early 1990s received significant waste discharge from rich heavy metal mining in the Ribeira River (approximately 5.5 metric tons per month of $\mathrm{Pb}, \mathrm{Zn}, \mathrm{Ag}, \mathrm{As}, \mathrm{Cd}, \mathrm{Cu}$, and $\mathrm{Cr}$, according to Tessler et al. (1987), Eysink et al. (1988) and Cetesb (1988, 2000, 2007). The area known as Cananéia (CAN) is located $50 \mathrm{~km}$ to the southwest. It includes preserved mangroves and excellent environmental quality, and uçá crab capture is substantial there (Duarte et al., 2014). Therefore, this region is important in analyses of the sublethal impacts on this species (Mendonça and Miranda, 2008; 
Table 1

Characteristics of the municipalities/areas sampled in the state of São Paulo (Brazil).

\begin{tabular}{|c|c|c|c|c|c|c|c|c|c|c|}
\hline \multirow{3}{*}{$\begin{array}{l}\text { Characteristic of } \\
\text { Municipality/Area } \\
\text { Main economic } \\
\text { activity }\end{array}$} & \multicolumn{5}{|l|}{ Central Coast } & \multicolumn{5}{|l|}{ Southern Coast } \\
\hline & \multirow{2}{*}{$\frac{\text { Cubatão }}{\text { Industry }}$} & \multirow{2}{*}{$\begin{array}{l}\text { São Vicente } \\
\begin{array}{l}\text { Commerce and } \\
\text { services }\end{array}\end{array}$} & \multirow{2}{*}{$\begin{array}{l}\text { Bertioga } \\
\begin{array}{l}\text { Tourism and } \\
\text { commerce }\end{array}\end{array}$} & \multirow[t]{2}{*}{ Mean \pm SD } & \multirow[t]{2}{*}{ Total $\Sigma$} & \multirow{2}{*}{$\begin{array}{l}\text { Iguape } \\
\text { Tourism, fish- } \\
\text { ing and } \\
\text { commerce }\end{array}$} & \multirow{2}{*}{$\begin{array}{l}\text { Cananéia } \\
\text { Fishing }\end{array}$} & \multirow{2}{*}{$\begin{array}{l}\text { Juréia } \\
\text { Ecotourism and } \\
\text { sustainable } \\
\text { extraction }\end{array}$} & \multirow[t]{2}{*}{ Mean \pm SD } & \multirow[t]{2}{*}{ Total $\Sigma$} \\
\hline & & & & & & & & & & \\
\hline Área $^{1}(\mathrm{~km}-)$ & 142,879 & 147,893 & 490,148 & - & 780,920 & $1,977,957$ & $1,239,376$ & 7924 & - & $3,225,257$ \\
\hline $\begin{array}{l}\text { Number of } \\
\text { inhabitants }\end{array}$ & 118,72 & 332,445 & 47,645 & - & 391,962 & 28,841 & 12,226 & $1285^{*}$ & - & 42,352 \\
\hline $\begin{array}{l}\text { Demographic } \\
\text { density }^{1}\left(\text { hab./ } / \mathrm{km}^{2}\right)\end{array}$ & 83,091 & 224,788 & 9721 & $105,866 \pm 109$ & 317,600 & 1458 & 986 & 162 & $868 \pm 655$ & 2606 \\
\hline $\mathrm{HDI}^{1}$ & 0.737 & 0.768 & 0.730 & $0.745 \pm 0.20$ & - & 0.726 & 0.720 & - & $0.723 \pm 0.04$ & - \\
\hline $\mathrm{GDP}^{2}(\times \mathrm{R} \$ 1000.00)$ & $63,481.45$ & $38,358.00$ & 8855.89 & $36,898 \pm 27,342$ & $110,695.34$ & 324.77 & 1347.06 & - & $835.91 \pm 722.86$ & 1671.83 \\
\hline GDP per capita ${ }^{2}$ (R\$) & $52,772.36$ & $11,388.65$ & $17,604.74$ & $27,255+22,315$ & $81,765.75$ & $11,177.76$ & $11,027.28$ & _- & $11,102+10,640$ & $22,205.04$ \\
\hline $\mathrm{HPI}^{3}(\%)$ & 21.30 & 15.00 & 25.00 & $20.43 \pm 5.05$ & 61.30 & 33.30 & 37.30 & - & $35.30 \pm 28.28$ & 70.60 \\
\hline Sanitation $^{4}(\%)$ & 75.14 & 87.08 & 30.81 & $64.34 \pm 29.64$ & - & - & - & - & - & - \\
\hline $\begin{array}{l}\text { Drainage basin } \\
\left(\mathrm{km}^{2}\right)\end{array}$ & 24,394 & $8581^{* *}$ & 61,291 & - & 94,266 & - & - & - & - & 17,068 \\
\hline $\begin{array}{l}\text { Metals (water and } \\
\text { sediment) }\end{array}$ & $\begin{array}{l}\mathrm{As}^{6}, \mathrm{Cd}^{6,12}, \mathrm{~Pb}^{6,11,14}, \mathrm{Cu}^{6}, \mathrm{Cr}^{6,11}, \mathrm{Hg}^{6,11}, \\
\mathrm{Ni}^{6,11}, \mathrm{Zn}^{6,11}\end{array}$ & $\begin{array}{l}\mathrm{Pb}^{6}, \mathrm{Cu}^{6,7,13}, \mathrm{Hg}^{6,11} \\
\mathrm{Ni}^{6,7}, \mathrm{Cr}^{7,11}, \mathrm{Zn}^{7}, \mathrm{Cd}^{12}\end{array}$ & $\begin{array}{l}\mathrm{As}^{6}, \mathrm{Cr}^{6,11} \\
\mathrm{Ni}^{6,11}, \mathrm{Cd}^{11}\end{array}$ & - & 8 Contaminants & $\mathrm{Pb}^{9,12}, \mathrm{Cu}^{12}$ & $\mathrm{Cd}^{10}$ & - & - & 3 Contaminants \\
\hline $\begin{array}{l}\text { Organochlorine pes- } \\
\text { ticides (water and } \\
\text { sediment) }\end{array}$ & $\begin{array}{l}\text { Alpha-BHC }{ }^{6}, \text { Delta-BHC }{ }^{6} \text {, Gamma- } \\
\text { BHC }^{6}\end{array}$ & $\begin{array}{l}\text { Alpha-BHC }{ }^{6} \text { Beta- } \\
\text { BHC }^{6}, \text { Delta-BHC } \\
\text { Gamma-BHC }\end{array}$ & - & - & 4 Contaminants & - & $\begin{array}{l}\mathrm{DDT}^{8}, \mathrm{DDE}^{8} \\
\mathrm{DDD}^{8}, \mathrm{HCB}^{8}\end{array}$ & - & - & 4 Contaminants \\
\hline PCBs (Sediment) & PCBs totais ${ }^{6}$ & - & - & - & 1 Contaminant & - & - & - & - & - \\
\hline PAHs (Sediment) ${ }^{6}$ & $\begin{array}{l}\text { Acenaphthene, Acenaphthylene, An- } \\
\text { thracene, Benzo-a-Anthracene, Ben- } \\
\text { zo-a-Pyrene, Chrysene, Dibenzo-a- } \\
\text { Anthracene, Phenanthrene, Fluor- } \\
\text { anthene, Fluorene, Naphthalene, } \\
\text { Pyrene }\end{array}$ & $\begin{array}{l}\text { Acenaphthylene, An- } \\
\text { thracene, Benzo-a- } \\
\text { Anthracene }\end{array}$ & - & - & 12 Contaminants & - & - & - & - & - \\
\hline
\end{tabular}

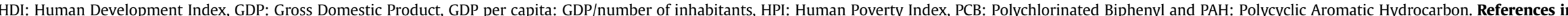

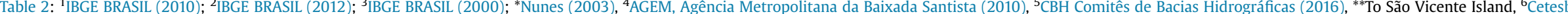

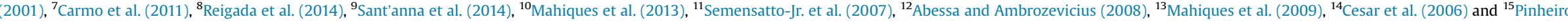
et al. (2013). The use of a hyphen (-) represents information that is not available. 
Pinheiro et al., 2012, 2013). The mangroves in Juréia (JUR) are located approximately $50 \mathrm{~km}$ northeast of Iguape, and this area is in an ecological station known as the Juréia-Itatins Ecological Station (EEJI). The human population is more limited in the region and is based on traditional extractive activities that are free of contaminants (Marques and Duleba, 2004; Pinheiro et al., 2013). The station is therefore considered effective in protecting local biodiversity (Bruner et al., 2001). In summary, Cananéia and Juréia are considered pristine estuarine regions of São Paulo State (Azevedo et al., 2009) where some cytological and hematological analyses in sea bass fish have not shown any sublethal damage (Kirschbaum et al., 2009; Seriani et al., 2013).

\subsection{Multi-level biological responses exhibited by U. cordatus}

\subsubsection{Genotoxicity via micronucleus Test (MN\%o): molecular level}

During the winter of 2013, adult male $U$. cordatus specimens (carapace width or $\mathrm{CW}>60 \mathrm{~mm}$ ) were captured by hand (see Pinheiro and Fiscarelli (2001)). They were in the intermolt stage and free of parasites. Five specimens per subarea were obtained $(n=15 /$ area), for a total of 90 specimens for the genotoxicity analysis. The animals collected underwent biometric procedures, including body size $(\mathrm{CW})$ measurement using precision calipers $(0.01 \mathrm{~mm})$ and total wet weight $(\mathrm{WW})$ measurement using a precision scale $(0.01 \mathrm{~g})$. A hemolymph sample was obtained from each crab in order to conduct the micronucleus test following a modified version of the protocol offered by Scarpato et al. (1990) and successfully employed by Nudi et al. (2010) and Pinheiro et al. (2013). The number of hemocytes (hyalinocytes) that contained micronuclei was recorded in relation to every 1000 cells analyzed (MN\%o), thus avoiding possible errors if granulocyte and semigranulocyte hemocytes were used (Hose et al., 1990; Martinez et al., 1999; and Matozzo and Marin, 2010). Micronucleated cells were identified according to the descriptions offered by Countryman and Heddle (1976), and were confirmed by the presence of cytoplasmic corpuscles less than $1 / 3$ of size of the nucleus (which were not connected to the micronuclei and which needed to exhibit similar staining results). Cells with more than three micronuclei were not considered.

\subsubsection{Cytotoxicity according to neutral red retention time (NRRT): physiological level}

Hemolymph samples were obtained from 10 specimens per subarea ( $n=30 /$ area), for a total of 180 samples for the cytotoxicity assay. First, the NRRT assay was applied to U. cordatus, with an adaptation to the protocol originally created by Lowe et al. (1995) for bivalve mollusks and subsequently adapted to crabs (Buratti et al., 2012). The slides were decontaminated with nitric acid (5\%) and then washed, air dried, and treated with a diluted poly-L-lysine solution (1:10 in distilled water) using $10 \mu \mathrm{L}$ per slide for hemocyte adhesion. The four following solutions were prepared: (1) a physiological solution (4.77 $\mathrm{g}$ of HEPES, $25.48 \mathrm{~g}$ of sodium chloride, $4.36 \mathrm{~g}$ of magnesium sulfate, $0.75 \mathrm{~g}$ of potassium chloride, $1.92 \mathrm{~g}$ of calcium chloride, $1 \mathrm{~L}$ of distilled water, and $\mathrm{pH} 7.36$ ); (2) a stock neutral red solution (22.8 $\mathrm{mg}$ of neutral red and $1 \mathrm{~mL}$ of DMSO); (3) a working solution ( $10 \mu \mathrm{L}$ of the stock solution and $5 \mathrm{~mL}$ of physiological solution); and (4) an anticoagulant solution ( $2.05 \mathrm{~g}$ of glucose, $0.8 \mathrm{~g}$ of sodium citrate, $0.42 \mathrm{~g}$ of sodium chloride, and $100 \mathrm{~mL}$ of distilled water). The anticoagulant and physiological solutions were mixed (a $3: 2$ ratio) using a $0.5-\mathrm{mL}$ filled hypodermic syringe $(1 \mathrm{~mL}$, provided with a $21 \mathrm{G}$ needle). These syringes were used to extract $0.5 \mathrm{~mL}$ of hemolymph per crab, and the samples were transferred into microtubes $(2 \mathrm{~mL})$ that were slightly homogenized and then placed onto specific shelves for 15$20 \mathrm{~min}$. Next, $40 \mu \mathrm{L}$ of a hemolymph, anticoagulant and physiological solution were dripped from each microtube on the surface of the previously prepared slides, which were kept in a humidified dark chamber (an acrylic box with paper moistened with distilled water) for 15 min so that the cells would better adhere to the slides. In addition, $40 \mu \mathrm{L}$ of working solution was dripped on the hemocytes on each slide, and these slides were then kept in the humidified dark chamber for $15 \mathrm{~min}$. Slides were covered using coverslips, and excess liquid was carefully removed using a filter paper. In the first hour, the slides were examined every $15 \mathrm{~min}$ under an optical microscope (400x) and, if necessary, after the second hour, every $30 \mathrm{~min}$. In contrast with micronucleus test, only granulocytes and semi-granulocytes were evaluated (Hose et al., 1990; Martinez et al., 1999; Matozzo and Marin, 2010). Lysosome size and color were determined to assess stress level abnormalities, as was cell shape (irregular=healthy; circular= stressed), these characteristics may also be altered by contaminants (Collier et al., 2013). Details of the criteria used to define granulocytes and semi-granulocytes as healthy or under stress are described by Lowe et al. (1995).

\subsubsection{Condition factor and crab density: population level}

Fulton's condition factor $(\mathrm{K})$ was measured in mature males from each area. It was calculated using on the following equation:

$K_{i}=W W_{i} /\left(C W_{i}\right)^{b}$

where $W W_{i}$ is the wet weight of the $i$-nth individual, recorded using a digital precision balance $(0.01 \mathrm{~g}), \mathrm{CWi}$ is the carapace width of the $i$-nth individual, measured using precision calipers $(0.05 \mathrm{~mm})$, and $b$ is the constant growth in weight, determined using the fit of the empirical points of the $\mathrm{WW} \times \mathrm{CW}$ relation for each area based on the power function $\left(W W=a C W^{b}\right)$, as indicated by Lima-Junior et al. (2002) and Pinheiro and Fiscarelli (2009). Therefore, the mean condition factor was calculated for each mangrove area and the differences were analyzed. The $U$. cordatus density of each mangrove subarea was estimated using the protocol established by Pinheiro and Almeida (2015). In this case, the areas were comprised of four squares of $5 \times 5 \mathrm{~m}\left(25 \mathrm{~m}^{2}\right)$ to which random sampling was applied. Two sites were near the margins of the estuary (approximately $15 \mathrm{~m}$ away from the estuary water) with $50 \mathrm{~m}$ between them, and the other two were positioned more deeply inside the forest (about $30 \mathrm{~m}$ away from the banks of the estuary). The total was therefore $100 \mathrm{~m}^{2}$ per subarea. The density (ind $\mathrm{m}^{-2}$ ) of each sample square was determined using the indirect method based on the number of open and closed burrows with biogenic activities (Pinheiro and Almeida, 2015) in which the presence of one crab per burrow is assumed (Wunderlich et al., 2008). $U$. cordatus density was represented as the average obtained in each mangrove area from twelve sampling units $\left(300 \mathrm{~m}^{2}\right)$.

\subsection{Environmental quality indicator: quantity of solid waste}

In addition to the environmental impacts obtained from a review of the literature, the quantity of solid waste $\left(\mathrm{g} \mathrm{m}^{-2}\right)$ by mangrove area or subarea was also used as an indicator of environmental quality. Solid waste is also a source of contamination for $U$. cordatus, and it was assumed that many types of contaminants are higher in places where there is a greater human presence (Abessa and Ambrozevicius, 2008; Cordeiro and Costa, 2010). To achieve this information, waste found in the sediment was collected from the same square sample used to estimate crab density. These items were placed in plastic bags and transported to the laboratory, where they were classified according to type (processed wood, plastic, glass, etc.), washed to remove mud, and dried in a forced ventilation oven $\left(60{ }^{\circ} \mathrm{C}\right.$ for $\left.72 \mathrm{~h}\right)$, until a constant weight was achieved on a digital precision scale $(0.01 \mathrm{~g})$. Dry 
weight average of solid waste by mangrove area was calculated for 12 sample squares $\left(300 \mathrm{~m}^{2}\right)$.

\subsection{Statistical analysis}

Excel and R 2.13.0 were used to design the figures and perform the statistical analyses (Ihaka and Gentleman, 1996). Results of the cytotoxicity tests (neutral red retention time, in minutes), genotoxicity tests (micronucleated cells per 1000 analyzed cells), solid waste volume $\left(\mathrm{g} \mathrm{m}^{-2}\right)$, and the condition factor and density (ind $\mathrm{m}^{-2}$ ) of $U$. cordatus were all represented by their averages ( \pm standard deviations) for each mangrove area. In all cases, the means were compared using ANOVA and a post hoc multiple comparison with Tukey's range test, confirming a normal distribution (Shapiro-Wilk test) and equality of variances, or homoscedasticity via Levene's test (Zar, 1999; Faraway, 2002). The average of each biological parameter (cytotoxicity, genotoxicity, condition factor, and crab density) were used to determine multilevel biological responses in relation to the contamination indicator (solid waste) based on a multifactorial analysis comprised of a principal component analysis (PCA), a distances of similarity analysis, and a cluster analysis based on Euclidean distance (Kaufman and Rousseeuw, 1990). Calculations were executed using an R package named FactoMineR (Husson et al., 2012), with a classification of each area clustered by similarity ( $Q$ mode).

The NRRT vs. MN association was determined using a Spearman's rank correlation coefficient and empirical points obtained from all mangrove subareas sampled. The statistical significance was $5 \%$ and the association was confirmed using tabulated data with $n$-2 degrees of freedom (Zar, 1999). A power function was applied to the empirical point of this relationship $\left(Y=a X^{b}\right)$, with interpretation by the coefficient of determination $\left(R^{2}\right)$.

\section{Results}

A total of 517 solid waste samples from the mangrove areas studied were divided into eight categories: plastic (85.5\%), processed wood $(8.9 \%)$, cloth $(2.7 \%)$, Styrofoam (1.0\%), paper $(0.8 \%)$, glass $(0.6 \%)$, rubber $(0.4 \%)$, and pieces of concrete $(0.2 \%)$. At the Juréia and Cananéia sites, there was no solid waste (in $\mathrm{g} \mathrm{m}^{-2 \text {; }}$ see Fig. 2), while the lowest average was found in Iguape $(0.4 \pm 0.9)$ and the highest was recorded in the central coast mangroves: SAV $(34.4 \pm 32.6)>\operatorname{BET}(22.2 \pm 26.6)>$ CUB $(18.9 \pm 32.1)$. The São

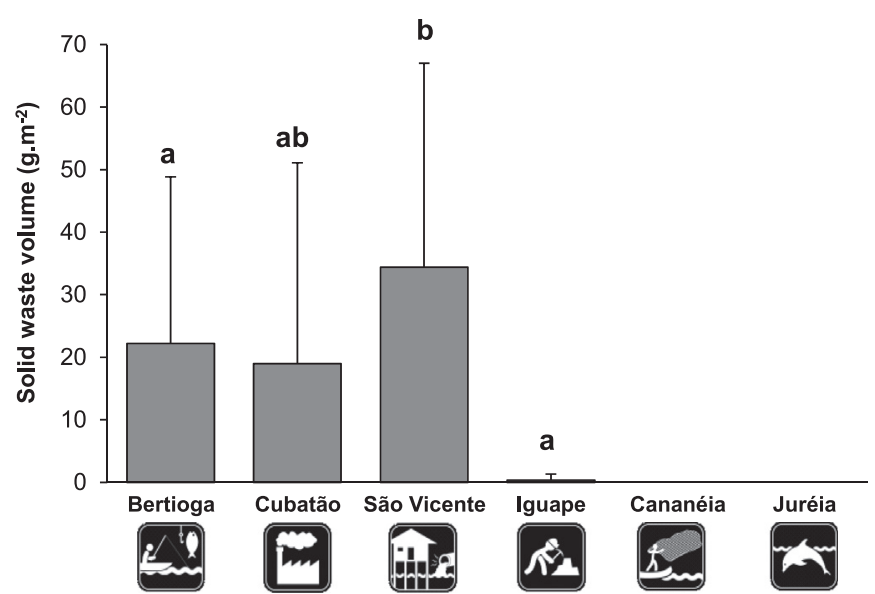

Fig. 2. Solid waste volume $\left(\mathrm{g} \mathrm{m}^{-2}\right)$ as an environmental impact indicator observed in mangrove areas in the state of São Paulo, Brazil. Bars indicate the average volume, vertical lines indicate standard deviation, and different letters above the bars represent statistical differences between mangrove areas as per ANOVA and Tukey's test $(P<0.05)$.
Vicente mangrove stood out not both solid waste volume and quantity (375 units), as well as for the variety of items (62.5\%). The solid waste from the São Vicente mangrove was represented by 328 pieces of plastic, 38 pieces of processed wood, 7 cloths, 1 piece of glass, and 1 piece of Styrofoam. A similar situation was recorded in the Cubatão mangrove, which presented an abundance that was three times lower (123 units) and more diverse (87.5\%). The $\mathrm{Cu}-$ batão waste consisted of 100 pieces of plastic, 6 cloths, 6 pieces of processed wood, 4 pieces of paper, 4 pieces of Styrofoam, 2 pieces of glass, and 1 piece of rubber. The Bertioga sample totaled only 20 solid waste units distributed across five categories (62.5\%), with 15 pieces of plastic, 2 pieces of processed wood, 1 cloth, 1 piece of Styrofoam, and 1 piece of concrete.

The animals used in the sublethal damage assessment had an average carapace width of $77.41 \mathrm{~mm}( \pm 5.53)$ and an average weight of $210.7 \mathrm{~g}( \pm 38.92)$. With the exception of the condition factor $(\mathrm{K})$, which did not differ statistically between the study areas (ranging from Cananéia $=4.6210^{-4} \pm 0.4210^{-4}$ to Iguape $=4.8210^{-4} \pm 0.4410^{-4}$ ), all of the biological responses presented statistical differences according to ANOVA. There were contrasts between some areas according to Tukey's test $(\mathrm{p}<0.05)$. Genotoxicity results (MN\%o) were found to be in the following mangrove order: SAV $(7.4 \pm 2.6)>[$ CUB $\quad(5.2 \pm 1.9)=$ BET $(5.0 \pm 1.3)=\operatorname{IGU}(3.8 \pm 2.5)]>$ [JUR $(0.7 \pm 1.0)=$ CAN $(0.4 \pm 0.6)]$ (Fig. 3A). A similar order occurred in the case of the cytotoxicity results, which were found to be as follows: CUB $(29.5 \pm 10.0)>$ [BET $(51.0 \pm 18.7)=$ SAV $(61.5 \pm 10.7)] \geq$ IGU $(71.0 \pm 14.7)>$ CAN $(141.0 \pm 51.8)>$ JUR $(260.0 \pm 42.7)$ (Fig. 3B). The average crab density was found to be in accordance with the sublethal responses observed: lower densities were found in mangrove areas that experienced more sublethal damage and human impact: [BET $(0.77 \pm 0.83)=$ CUB $\quad(0.99 \pm 0.68)=$ SAV $\quad(1.32 \pm 0.91) \leq$ IGU $(1.65 \pm 0.65)] \leq[$ CAN $(1.8 \pm 0.78)=$ JUR $(1.92 \pm 1.03)]$ (Fig. 3C).

The two biomarkers (NRRT and MN\%o) were found to share a significant negative correlation ( $r=-0.78 ; P<0.01$; Fig. 4). There is therefore evidence that they are antagonistic but that they reflect to the same sequence as the conservation status of mangroves studied. Empirical points of the NRRT vs. MN\%o correlation were adjusted by the power function, resulting in the equation $\mathrm{NRRT}=153.58 \mathrm{MN}^{-0.424}$ and $61.8 \%$ representation of the fitted empirical points.

These indicators show that the mangrove areas of Cubatão, São Vicente, and Bertioga experience greater human impact, while the mangroves of Juréia and Cananéia presented higher environmental quality. The Iguape area, on the other hand, remained in a relatively moderate position, regardless of the indicator (Chart 1).

It is important to note that, for the first three sites (greatest impact), the fourth site (moderate impact), and the last two sites (minor impact), there were no changes in mangrove areas associated with the indicators; there was only a change in the hierarchy within these groups, depending on the sensitivity of the indicator employed. These three groups (Group 1, Juréia and Cananéia; Group 2, Iguape; and Group 3, Cubatão, Bertioga, and São Vicente) were confirmed by multifactorial analysis (Fig. 5). The multi-level biological response proved to be compatible with the environmental quality indicator (solid waste). Thus, Group 3 was characterized as the areas experiencing the greatest sublethal damage associated with higher solid waste volumes and lower crab population densities, while the opposite occurred in Group 1. Similar to the information presented in Chart 1, Iguape (Group 2) was found to be between the other two groups.

\section{Discussion}

The use of biomarker responses such as micronuclei and lysosomal integrity in different species inhabiting various sites across 

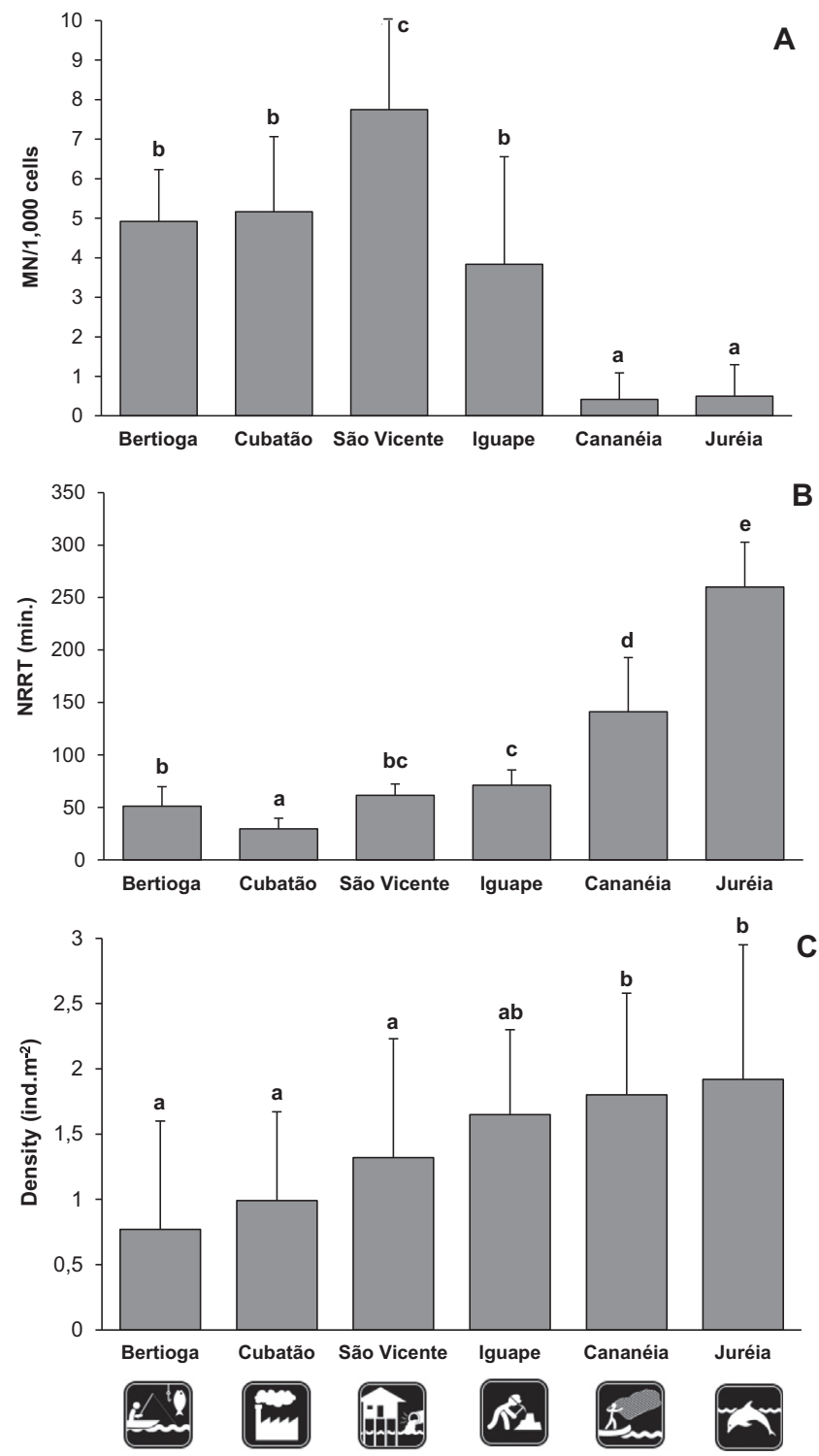

Fig. 3. Biological responses of the mangrove crab Ucides cordatus by mangrove area in state of São Paulo (Brazil), according to: (A) the number of micronucleated cells per thousand (MN\%o); (B) neutral red retention time assay (NRRT), in minutes; and (C) crab density (ind $\mathrm{m}^{-2}$ ). Bars indicate the average, vertical lines indicate the standard deviation, and different letters above the bars reflect statistical differences between averages according to ANOVA and a post hoc Tukey test $(P<0.05)$.

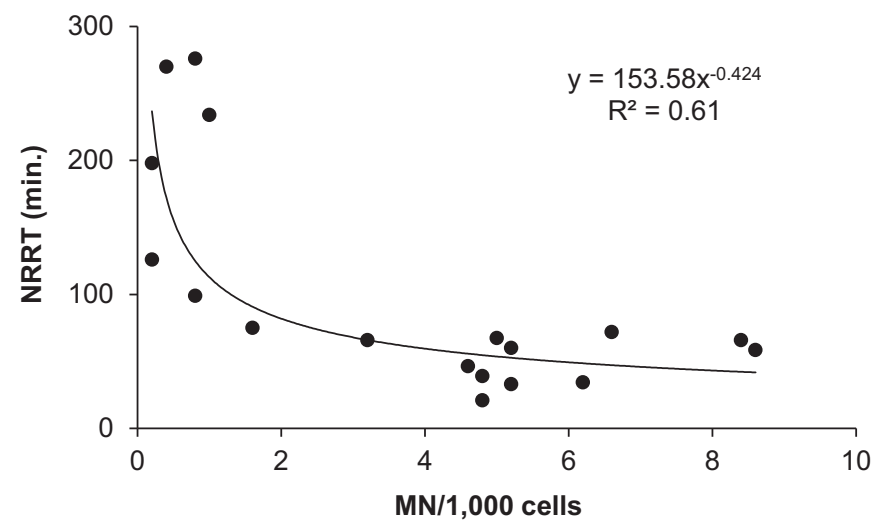

Fig. 4. Relationship between NRRT (time of lysosome integrity by neutral red assay, in minutes) and MN\%o (number of micronucleated cells per thousand analyzed) in the mangrove crab Ucides cordatus, with fit of the empirical points via power function.

\begin{tabular}{|c|l|}
\hline Indicator & \multicolumn{1}{c|}{$\begin{array}{c}\text { Conservation Hierarchy } \\
\text { of Mangrove Areas }\end{array}$} \\
\hline Genotoxicity $(\mathrm{MN} \%)$ & $\mathrm{CUB}>(\mathrm{BET}=\mathrm{SAV}) \geq \mathrm{IGU}>\mathrm{CAN}>\mathrm{JUR}$ \\
\hline Citotoxicity $(\mathrm{NRRT})$ & $\mathrm{SAV}>(\mathrm{CUB}=\mathrm{BET}=\mathrm{IGU})>(\mathrm{JUR}=\mathrm{CAN})$ \\
\hline Crab Density $(\mathrm{DENS})$ & $(\mathrm{BET}=\mathrm{CUB}=\mathrm{SAV}) \leq \mathrm{IGU} \leq(\mathrm{CAN}=\mathrm{JUR})$ \\
\hline Solid Waste $(\mathrm{SW})$ & $\mathrm{SAV} \geq(\mathrm{CUB}=[\mathrm{BET}=\mathrm{IGU}])$ \\
\hline
\end{tabular}

Chart 1. Decreasing hierarchy of mangrove area conservation based on average values for each indicator and according to their statistical differences (ANOVA; $P<0.05) . \quad C U B=$ Cubatão; $\quad B E T=$ Bertioga; $\quad S A V=$ São Vicente; $\quad$ IGU = Iguape; $\mathrm{CAN}=$ Cananéia; and JUR $=$ Juréia.

the region covered by the OSPAR Convention revealed the relevance of cytotoxicity and genotoxicity levels in ecosystem assessments. Lysosomal membrane stability has recently been adopted by the UNEP as part of the first tier of techniques for assessing harmful impacts within the Mediterranean Pollution Programme (Ospar, 2013).

The rationale for applying cytogenetic assays to ecologically relevant species is that, after the contaminants reach cells, whether by contact, absorption, or ingestion (Rainbow, 1997, 2007; Rainbow and Black, 2005; Ahearn et al., 2004), concentrations that exceed animals' physiological capacities (metabolism/excretion) may be immobilized by detoxification processes, thus avoiding sublethal damage (Tsarpali and Dailianis, 2012; Newman, 2013). Contaminants may also reach generic common targets (e.g. lysosomes or nuclei), a process which damages genetic material and causes dysfunction of cellular processes. This process has been mechanistically linked with many aspects of pathology associated with toxicity and degenerative diseases (Moore et al., 2006). Genetic damage can lead to genetic erosion and may especially compromise species resilience to selective pressures in the environment (Bijlsma and Loeschcke, 2012). Early physiological damage includes lipid peroxidation of the cell membranes caused by free radicals that alter their structures and permeability, a change which may result in apoptosis. This process is associated with natural aging and may occur naturally in organisms (Tsarpali and Dailianis, 2012; Newman, 2013). However, sublethal changes are potentiated by xenobiotic activity (Wei and Yang, 2015).

This study presents baseline values, which may be understood as normality parameters (or references) for determining cytotoxicology and genotoxicity in studies on $U$. cordatus. Scarpato et al. (1990) defined normal genotoxicity values as $\mathrm{MN} \%<<4$, but this threshold is based on the responses of bivalve mollusk specimens (Mytilus galloprovincialis) unaffected by xenobiotics. Therefore, interspecific variation is expected. Fossi et al. (2000) confirmed this value for the crab Carcinus aestuarii, but according to Nudi et al. (2010), $U$. cordatus exhibits greater genetic sensitivity. This argument was confirmed in the current study; areas with lower human impact (Cananéia) and pristine areas (Juréia) had lower genotoxicity averages $(\mathrm{MN} \%<2)$. Therefore, it is possible to assume this value as a mean genotoxicity baseline for $U$. cordatus, thus allowing for the categorization of specimens from more impacted mangrove areas such as Cubatão and Bertioga. Meanwhile, São Vicente genotoxicity values were found to be four times higher than this reference value. In a study consistent with this evidence, Pinheiro and Toledo (2010) reported a genotoxicity value of 11.5 MM\% in one specimen with cheliped malformation captured in São Vicente, which is five times higher than the environmental quality baseline established in this study.

In the case of cytotoxicity, the baseline substantially surpassed the values reported in other studies on species from different taxonomic groups (Svendsen et al., 2004; Buratti et al., 2012). The 

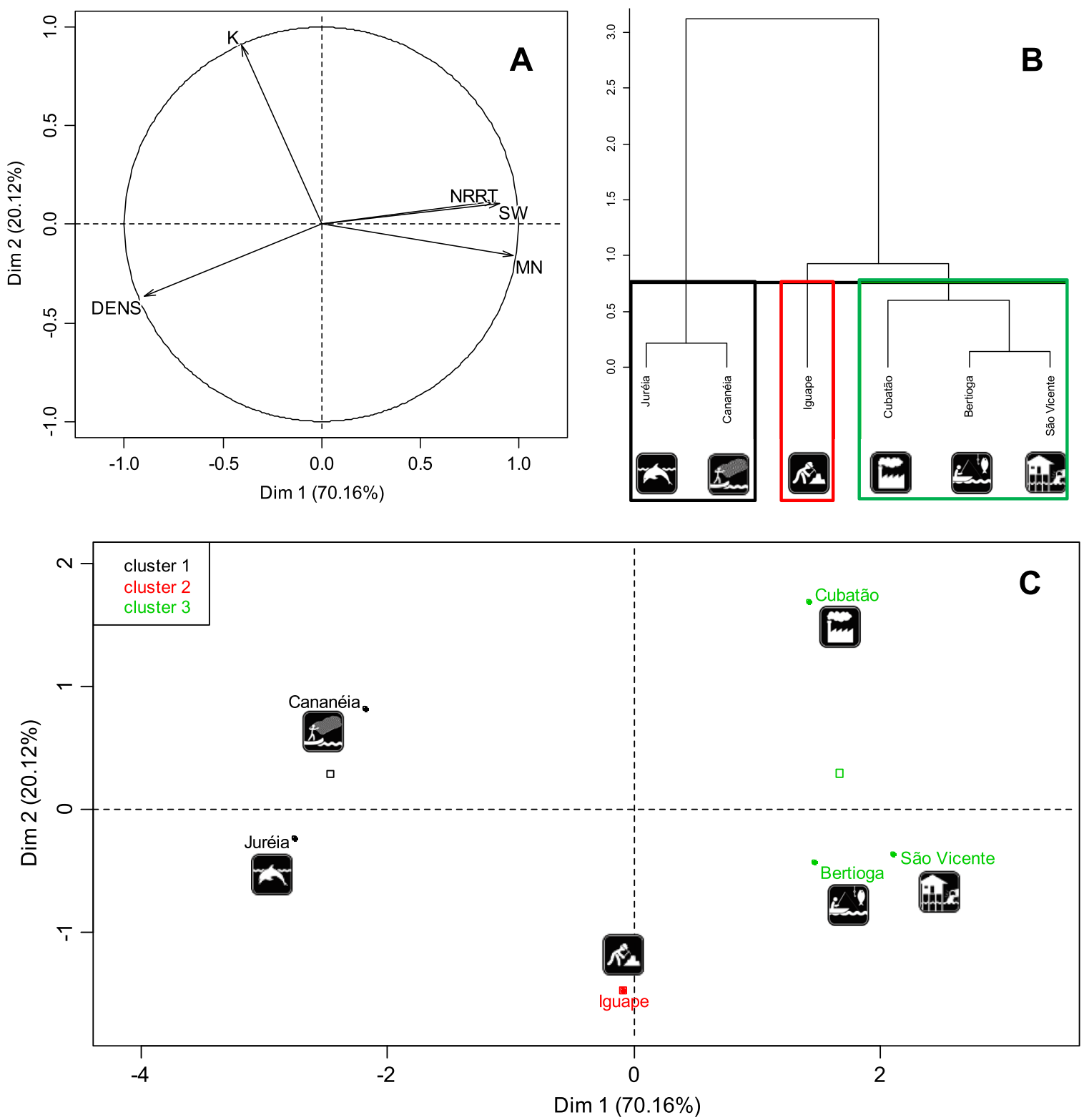

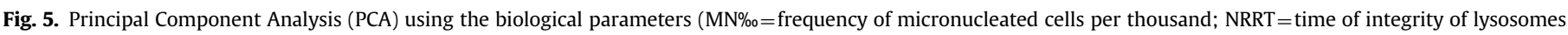

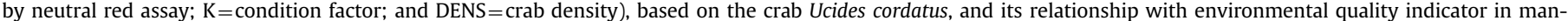

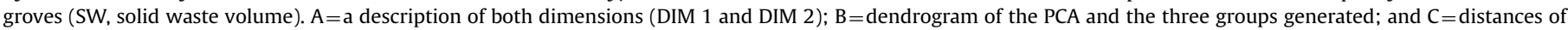

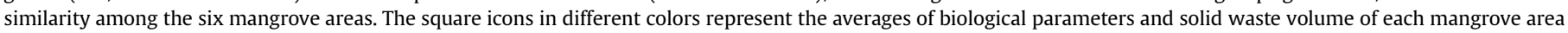

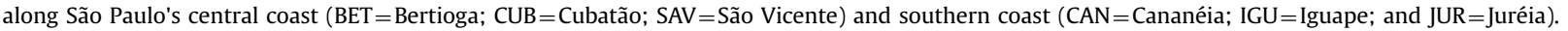

average NRRT for the crab Carcinus maenas was $70 \mathrm{~min}$ in the control treatment (Buratti et al., 2012; Aguirre-Martínez et al., 2013). The NRRT was almost three times higher (205 min) when the same nature experiments were applied to the shrimp Fenneropenaeus chinensis (Yao et al., 2008). In the Juréia mangroves, the average NRRT for $U$. cordatus specimens was $260 \mathrm{~min}( \pm 42.7)$, with a reduced coefficient of variation (13.3\%). This result reflects the reliability of the estimate, as well as the pristine condition of this ecological station. During the experiment, only cells of crabs from Juréia and Cananéia displayed dye leakage from the lysosomes into the cytosol approximately two hours after exposure.

The effects of contamination on the parameters involving population dynamics are also difficult to correlate, though Jergentza et al. (2004) and Brink et al. (2007) have linked this negative influence to other crustacean species. Population indicators usually respond belatedly to the chronic effects of disturbances to the natural environment and are therefore less sensitive and less powerful in environmental monitoring studies (Adams, 1990; Fishelson et al., 1999). Crab density is a population parameter for which establishing a baseline (reference) is more complex (Pauly, 1995), since environmental support capacity (ecosystem function) is the most important factor in determining population size (Gamfeldt et al., 2015). As an example, mangroves of the northern and northeast regions of Brazil hold more biomass than those in the south and southeast (Schaeffer-Novelli and Cintrón, 1986). This difference is reflected in differences in $U$. cordatus density, which is higher at more productive sites; it ranges from 3.7 ind $\mathrm{m}^{-2}$ (Goes et al., 2010) to 5.7 ind $\mathrm{m}^{-2}$ (Fernandes and Carvalho, 2007). In contrast, less productive mangrove areas such as those in southeastern and southern Brazil may exhibit densities that are three to five times lower. Examples of densities reported in these regions include 1.1 ind $\mathrm{m}^{-2}$ (Branco, 1993), 1.7 ind $\mathrm{m}^{-2}$ (Blankensteyn et al., 1997), and 2.1 ind $\mathrm{m}^{-2}$ (Wunderlich et al., 2008). However, the sampling in the current study was standardized in similar 
mangrove areas according to tree composition, vegetation structure, height of flooding by tides, and productivity by leaves on the sediment, and thus approached equivalent ecosystem function (Gamfeldt et al., 2015). Hence, differences observed in U. cordatus population density between the mangrove areas are likely a real reflection of the regional human impact gradient (Viana et al., 2014; Barrilli et al., 2015). However, it's admitted that there are, perhaps, other crucial factors that have not yet been identified (and which were therefore not measured in this study) that may influence the population density apart from contamination. It is also believed that harvesting crabs at the different sites could not have interfered with the results, given the fact that Cananéia is the highest producer of crabs of the state of São Paulo. It has experienced an increase in the crab population (Duarte et al., 2014) and was found to have the second highest densities observed in present study.

Meanwhile, the condition factor $(\mathrm{K})$ was not found to differ significantly between mangrove areas; the reduced variation between the mean values of this population parameter was insufficient for determining environmental quality. Therefore, $\mathrm{K}$ has not been confirmed as a good descriptor in multi-level analysis.

In addition to the use of baseline biomarkers in multi-level analysis, the knowledge of their response sensitivity is also relevant to the diagnosis of mangrove conservation status. It is known, for example, that some genotoxicity tests are highly sensitive to DNA damage, even at reduced concentrations of pollutants (Monserrat et al., 2007). This fact has been confirmed in micronucleus tests on fish (Cavas et al., 2005; Deguchia et al., 2007; Adam et al., 2010; Sponchiado et al., 2011; Arslan et al., 2015), mollusks (BURGEOT et al., 1995; Eskandari et al., 2012; Sacchi et al., 2013; Kandroo et al., 2015), and crustaceans (Fossi, 2000; Nudi et al., 2010; Klobučar et al., 2012; Rocha et al., 2012; Pinheiro et al., 2013), even when the exposure time to a xenobiotic was $24 \mathrm{~h}$ or less.

Neutral red retention time is a biomarker known for its effective response to cytotoxic effects, since it is promoted by both organic and inorganic contaminants (Dailianis et al., 2003; Svendsen et al., 2004; Tsarpali and Dailianis, 2012; Toufexia et al., 2013). Such analyses have shown this high sensitivity to be a physiological indicator that reflects its responsiveness to the higher concentrations of xenobiotics to which organisms are exposed (Lowe et al., 1995; Svendsen et al., 2004; Yao et al., 2008).

For these reasons, the choice of parameters that are both sufficiently sensitive and effective in detecting environmental impact, as well as the selection of mangrove areas that are similar in structure and plant species composition, were decisive conditions for the success of the multi-level analysis approach used in this study. Toxicity at genetic and physiological levels may result in cell death, which is likely to damage tissues, organs, and the body as a whole. Over time, these changes often become irreversible impacts at the population and/or community level (Bonassi et al., 2000; Neri et al., 2003; Svendsen et al., 2004; Terlizzi et al., 2005). Because of this, sublethal damages may be considered to be prepathological indicators (Tsarpali and Dailianis, 2012), despite a lack of findings showing an impact on the population. This study confirms the association between sublethal damage and population parameters (crab density), a finding which supports the ecological effectiveness of the biomarkers. The results also show that, the crabs experienced more sublethal damage and lower population densities in the more highly impacted areas (Cubatão and Bertioga). The opposite was found to occur in the areas of least impact (Juréia and Cananéia) (see Tables 1 and 2). These results indicate that, in the case of $U$. cordatus, the cellular-level parameters (MN\%o and NRRT) combined with population-level parameters (density) are sufficiently effective in diagnosing the quality of the mangroves studied using a multi-level biological responses approach. Furthermore, the present study also confirms all of the evidence available in the literature regarding human impact on these mangrove areas. An original comparative approach for establishing ecological status is provided herein and produced the following results: Juréia and Cananéia = conserved areas; Bertioga, São Vicente, and Cubatão=very impacted areas; and Iguape $=$ an area experiencing moderate impact (see Chart 1 and Table 2). While all six mangrove areas have a human impact gradient, the amplitude of multi-level biological responses varies vary considerably, from a complete absence of damage (conserved areas) to sublethal effects (very impacted areas). Thus, when the biological response indicators are combined with the environmental quality indicator (solid waste) and the available historical information on the mangrove areas, recommended baseline values for biological responses can be provided in order to diagnose and categorize the ecological conservation status of this ecosystem. Therefore, three categories of impact are proposed herein: probably no impact (PNI); probable low impact (PLI), and probable high impact (PHI). These categories are based on the results of the genotoxicity assay (MN\%o), the cytotoxicity assay (NRRT), and the density (DENS) of $U$. cordatus, and damage categories are presupposed (genetic, physiological, and population-level categories, respectively). It is important to note that the proposed model available in Table 2 represents an impact gradient, so its applicability to other mangroves located in the Western Atlantic is encouraged. Multi-level biological response indicators that exceed the values recorded in conserved mangrove areas (Juréia and Cananéia) may be considered abnormal and indicative of local anthropogenic disturbances. Thus, it is possible to confirm the existence of genetic, physiological, and population impacts on the uçá crab in $66.6 \%$ of the mangroves located in São Paulo, which is Brazil's most industrialized area and the region with the greatest human density in the country (Marques et al., 2012). This situation could be reversed through environmental monitoring (Theodore and Dupont, 2012), with or without quantifying the accumulation of pollutants. There is evidence here of the effectiveness of $U$. cordatus as an indicator species for determining the conservation statuses of mangrove areas.

In conclusion, the success of multi-level biological responses is recognized in the establishment of baseline values for use in categorizing the ecological statuses of mangrove areas. This integrated, fast, sensitive, and relatively inexpensive approach may serve as a precursor to a determination of the overall conservation status of mangroves in the Western Atlantic based on the use of the crab $U$. cordatus as a sentinel species (biological model) in tropical ecotoxicology. This information may encourage environmental institutions to prioritize effective actions directed toward environmental and biota conservation. Using this preliminary mangrove categorization, we can avoid expenses resulting from pollutant testing in areas without probable impact (PNI), and we

\section{Table 2}

Damage categories suggested for mangrove areas ( $\mathrm{PNI}=$ probably no impact, $\mathrm{PLI}=$ probable low impact, and $\mathrm{PHI}=$ probable high impact), with an indication of baseline values for genotoxicity (MN\%o), cytotoxicity (NRRT), and crab density (DENS) for $U$. cordatus, based on solid waste volume and historic contamination of the mangrove areas in state of São Paulo, Brazil: Central Coast (BET=Bertioga, $\mathrm{CUB}=$ Cubatão, and $\mathrm{SAV}=\mathrm{São}$ Vicente) and Southern Coast (CAN=Cananéia, $\mathrm{JUR}=$ Juréia, and IGU = Iguape).

\begin{tabular}{lllll}
\hline $\begin{array}{l}\text { Damage } \\
\text { category }\end{array}$ & $\begin{array}{l}\text { Genotoxicity } \\
\text { (MN/1000) }\end{array}$ & $\begin{array}{l}\text { Cytotoxicity } \\
\text { (NRRT, in min.) }\end{array}$ & $\begin{array}{l}\text { Crab den- } \\
\text { sity (ind. } \\
\mathbf{m}^{-2} \text { ) }\end{array}$ & $\begin{array}{l}\text { Mangrove } \\
\text { areas }\end{array}$ \\
\hline PNI & $<3$ & $>120$ & $>1.7$ & JUR and CAN \\
PLI & $3-5$ & $60-120$ & $1-1.7$ & IGU \\
PHI & $>5$ & $<60$ & $<1$ & CUB, SAV and \\
& & & BET \\
\hline
\end{tabular}


can direct financial resources to optimal studies on xenobiotics in impacted mangrove areas. Only with a more specific approach and a more refined sampling grid are we able to identify the main sources of pollution in order to ultimately reduce it and mitigate its effects.

\section{Acknowledgments}

The authors would like to thank the São Paulo State Research Foundation (FAPESP) for awarding financial aid to MAAP for the Uçá III Project (FAPESP Case \# 2009/14725-1) and a Ph.D. scholarship to LFAM (Case \# 2010/01552-9). The authors are also grateful to the Brazilian National Council for Scientific and Technological Development (CNPq) for a scientific productivity grant (triennium 2010-2012) to MAAP (Case \# 302813/2010-1) and CDSP. The authors would like to thank biologists Pablo P.G. Silva, Sérgio O. Asche, Vanessa S. Soares, Bruna T. Souza, Kátia V.C. Sousa, Stephany C. Leitão, Fernanda F. Lopes, Gilmar Giraldelli, Leonardo M. S. Mesquita, Luis F. Natálio, Maria E. Laranjeira, Michel T. Angeloni, Rodolfo Probst, Rodrigo F. Malimpensa and André L.P. Souza for their support in the field expeditions and laboratory activities. In additions, the authors are grateful to Gustavo H.S. Pinheiro for preparing the map and icons representing the mangrove areas in this study. Data was obtained with permanent authorization to collect zoological material provided by the Brazilian Institute of the Environment and Renewable Natural Resources (SISBIO/IBAMA) to MAAP (\# 13581-1), as well as the authorization from the Brazilian Forest Institute's Scientific-Technical Commission (COTEC/FF) (SMA Case \# 260108-009.809/2010), to perform sample collections in the Juréia-Itatins Ecological Station (JIES).

\section{References}

Abessa, D.M.S., Ambrozevicius, A.P., 2008. Poluição aquática e tratamento de esgotos, Cap. 04, 41-54p. In: Oliveira, A.J.F.C., Pinheiro, M.A.A., Fontes, R.F.C. (Orgs.). Panorama Ambiental da Baixada Santista. Universidade Estadual Paulista - Campus Experimental do Litoral Paulista, 1ª Edição, ISBN 978-85-6149802-3, São Vicente (SP), 127p.

Adam, M.L., Torres, R.A., Sponchiado, G., Motta, T.S., Oliveira, C.M.R., Carvalho-Filho, M.A., Correia, M.T.S., 2010. Environmental degradation at a public park in Southern Brazil as revealed through a genotoxicity test (MN) on peripheral blood cells from Poecilia vivipara (Teleostei). Water Air Soil Pollut. 211, 61-68.

Adams, S.M., 1990. Status and use of biological indicators for evaluating the effects of stress on fish. Am. Fish. Soc. Symp. 8, 1-8.

Agem, 2010. Agência Metropolitana da Baixada Santista. Disponível em: 〈http:// www.agem.sp.gov.br>, (acessed 27.01.16).

Aguirre-Martínez, G.V., Buratti, S., Fabbri, E., Del Valls, T.A., Martín-Díaz, M.L., 2013. Environ. Monit. Assess. 185, 3783-3793.

Ahearn, G.A., Manadal, P.K., Mandal, A., 2004. Mechanisms of heavy-metal sequestration and detoxification in crustaceans: a review. J. Comp. Physiol. B 174 439-452.

Amiard-Triquet, C., Cossu-Leguille, C., Mouneyrac, C., 2013. Biomarkers of defense, tolerance and ecological consequences. In: Amiard-triquet, C., Amiard, J.C. Rainbow, P.S. (Eds.), Ecological Biomarkers. CRC Press/Taylor \& Francis Group, United States, p. 450

Arslan, O.C., Boyacioğlu, M., Parlak, H., Katalay, S., Karaaslan, M.A., 2015. Assessment of micronuclei induction in peripheral blood and gill cells of some fish species from Aliağa Bay Turkey. Mar. Pollut. Bull. 94 (1-2), 48-54.

Azevedo, J.S., Serafim, A., Braga, E.S., Fávaro, D.I., Bebianno, M.J., 2009. Biomarkers of exposure to metal contamination and lipid peroxidation in the benthic fish Cathorops spixii from two estuaries in South America, Brazil. Ecotoxicology 18 (8), 1001-1010.

Barrilli, G.H.C., Rocha, O., Negreiros, N.F., Verani, J.R., 2015. Influence of environmental quality of the tributaries of the Monjolinho River on the relative condition factor $(\mathrm{Kn})$ of the local ichthyofauna. Biota Neotrop. 15 (1), 1-9.

Beltrame, M.O., De Marco, S.G., Marcovecchio, J.E., 2010. Influences of sex, habitat and seasonality on heavy-metal concentrations in the burrowing crab (Neohelice granulata) from a coastal lagoon in Argentina. Arch. Environ. Contam. Toxicol. 58 (3), 746-756.

Beltrame, M.O., De Marco, S.G., Marcovecchio, J.E., 2011. The burrowing crab Neohelice granulata as potential bioindicator of heavy metals in estuarine systems of the Atlantic coast of Argentina. Environ. Monit. Assess. 172, 379-389.

Blankensteyn, A., Cunha Filho, D., Freire, A.S., 1997. Distribuição, estoques pesqueiros e conteúdo protéico do caranguejo do mangue Ucides cordatus (Ocypodidae) nos manguezais da Baía das Laranjeiras Pr. Arq. Biol. Tecnol. 40 (2), 331-349.

Bonassi, S., Hagmar, L., Strombert, U., Montagud, A.H., Tinnerbert, H., Forni, A., Heikkila, P., Wanders, S., Wilhardt, P., Hansteen, I.L., Knudsen, L.E., Norppa, H., 2000. European study group on cytogenetic biomarkers and heath chromosomal aberrations in lymphocytes predict human cancer independently of exposure to carcinogens. Cancer Res. 60, 1619-1625.

Branco, J.O., 1993. Aspectos bioecológicos do caranguejo Ucides cordatus (Linnaeus 1763) (Crustacea, Decapoda) do manguezal do Itacorubi, Santa Catarina, BR. Arq. Biol. Tecnol. 36 (1), 133-148.

Brasil, 2006. Departamento de Água e Energia Elétrica. Plano Estadual de Recursos Hídricos: 2004/2007 - Resumo. São Paulo: DAEE e Conselho Estadual de Recursos Hídricos. 92p.

Brink, P.J.V., Baveco, J.M.H., Verboom, J., Heimbach, F., 2007. An individual-based approach to model spatial population dynamics of invertebrates in aquatic ecosystems after pesticide contamination. Hazard/Risk Assess. 26 (10), 2226-2236.

Bruner, A.G., Gullison, R.E., Rice, R.E., Fonseca, G.A.B., 2001. Effectiveness of parks in protecting tropical biodiversity. Science 291, 125-128.

Brunetti, R., Majone, F., Gola, I., Beltrame, C., 1988. The micronucleus test: examples of application to marine ecology. Mar. Ecol. Prog. Ser. 44, 65-68.

Bijlsma, R., Loeschcke, V., 2012. Genetic erosion impedes adaptative responses to stressful environments. Evolut. Appl. 5 (2), 117-129.

Buratti, S., Ramos-Gómez, J., Fabbrini, E., Delvalls, T.A., 2012. Application of neutral red retention assay to caged clams (Ruditapes decussatus) (and crabs (Carcinus maena)s) (in the assessment of dredged material). Ecotoxicology 21, 75-86.

Burgeot, T., His, E., Galgani, F., 1995. The micronucleus assay in Crassostrea gigas for the detection of seawater genotoxicity. Mutat. Res. 342, 125-140.

Cannicci, S., Bartolini, F., Dahdouh-Guebas, F., Fratini, S., Litulo, C., Macia, A., Mrabu, E.J., Penha-Lopes, G., Paula, J., 2009. Effects of urban wastewater on crab and mollusc assemblages in equatorial and subtropical mangroves of East Africa. Estuar. Coast. Shelf Sci. 84, 305-317.

Caricato, R., Lionetto, M.G., Schettino, T., 2010. Seasonal variation of biomarkers in Mytilus galloprovincialis sampled inside and outside Mar Piccolo of Taranto (Italy). Chem. Ecol. 26 (1), 143-153.

Carmo, C.A., Abessa, D.M., Neto, J.G.M., 2011. Metais em águas, sedimentos e peixes coletados no estuário de São Vicente -SP, Brasil. O Mundo da Saúde 35 (1), $64-70$.

Cavas, T., Garanko, N.N., Victor, V. Arkhipchuk, 2005. Induction of micronuclei and binuclei in blood, gill and liver cells of fishes subchronically exposed to cadmium chloride and copper sulphate. Food Chem. Toxicol. 43 (4), 569-574.

Cbh, 2016. Comitê de Bacias Hidrográficas. Sistema integrado de gerenciamento de recursos hídricos do estado de São Paulo. Disponível em: 〈http://www.sigrh.sp. gov.br>, (acessed 27.01.16).

Cesar, A., Pereira, C.D.S., Santos, A.R., Abessa, D.M.S., Fernández, N., Choueri, R.B. Delvalls, T.A., 2006. Ecotoxicological assessment of sediments from the Sanos and São Vicente Estuarine System - Brazil. Braz. J. Oceanogr. 54 (1), 55-63.

Cetesb, 1988. Companhia de Tecnologia de Saneamento Ambiental. Metais pesados no Vale do Ribeira e em Iguape - Cananéia. São Paulo. 7p.

Cetesb, 2000. Companhia de Tecnologia de Saneamento Ambiental. Avaliação da qualidade do Rio Ribeira de Iguape e afluentes, São Paulo, 33p.

Cetesb, 2001. Companhia de Tecnologia de Saneamento Ambiental. Sistema Estuarino de Santos e São Vicente. Relatório do Programa de Controle de Poluição. São Paulo (SP), $137 \mathrm{p}+46$ pranchas.

Cetesb, 2007. Companhia de Tecnologia de Saneamento Ambiental. Relação de áreas contaminadas - Novembro de 2007 - Relação por municípios. 〈http:| www.cetesb.sp.gov.br/Solo/areas_contaminadas/texto_areas_cont_nov_08.pdf), (acessed 02.08.15)

Christofoletti, R.A., Hattori, G.Y., Pinheiro, M.A.A., 2013. Food selection by a mangrove crab: temporal changes in fasted animals. Hydrobiologia 702, 63-72. http://dx.doi.org/10.1007/s10750-012-1307-6.

Collier, T.K., Chiang, M.W.L., Au, D.W.T., Rainbow, P.S., 2013. Biomarkers currently used in environmental monitoring. In: Amiard-Triquet, C., Amiard, J.C., Rainbow, P.S. (Eds.), Ecological Biomarkers. CRC Press/Taylor \& Francis Group, United States, p. 450.

Cordeiro, C.A.M.M., Costa, T.M., 2010. Evaluation of solid residues removed from a mangrove swamp in the São Vicente Estuary, SP, Brazil. Mar. Pollut. Bull. 60, 1762-1767.

Countryman, P.I., Heddle, J.A., 1976. The production of micronuclei from chromosome aberrations in irradiated cultures of human lymphocytes. Mutat. Res. 41, 321-332.

Cunha-Lignon, M., 2014. Monitoramento de bosques de mangue do Estado de São Paulo, Brasil. Relatório Final de Pesquisa, CNPq Edital Universal (Proc. no. 472419/2011-0), Período 01/2012 - 01/2014, 52p.

Cunha-Lignon, M., Kampel, M., Dahdouh-Guebas, F. 2011a. Urban mangrove dynamics under increasing anthropogenic pressure: Analysis of remote sensing data and Brazilian legislation. In: Proceedings of the International Conference: Meeting on Mangrove Ecology, Functioning and Management (MMM3), VLIZ Special Publication 57, 47.

Cunha-Lignon, M., Kampel, M., Menghini, R.P., Schaeffer-Novelli, Y., Cintrón, G., Dahdouh-Guebas, F., 2011b. Mangrove forests submitted to depositional processes and salinity variation investigated using satellite images and vegetation structure surveys. J. Coast. Res. 64 (1), 344-348.

Dailianis, S., Domouhtsidou, G.P., Raftopoulou, E., Kaloyianni, M., Dimitriadis, V.K., 2003. Evaluation of neutral red retention assay, micronucleus test, 
acetylcholinesterase activity and a signal transduction molecule (cAMP) in tissues of Mytilus galloprovincialis (L.), in pollution monitoring. Mar. Environ. Res. 56, 443-470.

Deguchia, Y., Toyoizumi, T., Masuda, S., Yasuhara, A., Mohri, S., Yamada, M., Inoue, Y., Kinae, N., 2007. Evaluation of mutagenic activities of leachates in landfill sites by micronucleus test and comet assay using goldfish. Mutat. Res./Genet. Toxicol. Environ. Mutagen. 627 (2), 178-185.

Depledge, M.H, Amaral-Mendes, J.J., Daniel, B., Halbrook, R.S., Kloepper-Sams, P., Moore, M.N., Peakall, D.B. 1993. The Conceptual Basis of the Biomarker Approach. In: Peakall, D.B., Shugart, L.R. (Eds.) Biomarkers. NATO ASI Series, 119p.

Dissanayake, A., Galloway, T.S., Jones, M.B., 2011. Seasonal differences in the physiology of Carcinus maenas (Crustacea: Decapoda) from estuaries with varying levels of anthropogenic contamination. Estuar. Coast. Shelf Sci. 93 (4), 320-327.

Duarte, L.F.A., Duran, R.S., Mendonça, J.T., Pinheiro, M.A.A., 2014. The fishery for the 'uçá'- crab Ucides cordatus (Linnaeus, 1763) in a mangrove area in Cananéia, State of São Paulo, Brazil. I. Fishery performance, exploitation patterns and factors affecting the catches. Braz. J. Oceanogr. 62 (3), 187-199.

Eichler, P.P.B., Eichler, B.B., David, C.J., Miranda, L.B., Sousa, E.C.P.M., 2006. The estuary ecosystem of Bertioga, São Paulo, Brazil. J. Coast. Res. (Spec. Issue 39), $1110-1113$.

Environment Canada, 1999a. Canadian Sediment Quality Guidelines for the Protection of Aquatic Life. Summary Tables. 〈http://www.ec.gc.ca〉.

Environment Canada, 1999b. Canadian Water Quality Guidelines for the Protection of Aquatic Life. Summary Tables. 〈http://www.ec.gc.ca〉.

Eskandari, S., Mozdarani, H., Moradi, A.M., Shahhosseiny, M.H., 2012. Cytogenetic damage induced by crude oil in Anodonta cygnea (Mollusca, Bivalvia) assessed by the comet assay and micronucleus test. J. Mar. Sci. Eng. 2 (4), 215-224.

Eysink, G.G.J., Pádua, H.B., Piva-Bertoletti, A.E., Martins, M.C., Pereira, D.N., 1988. Metais pesados no Vale do Ribeira e Iguape-Cananéia. Ambiente: Rev. CETESB Tecnol. 2 (1), 6-13.

Faraway, J.J., 2002. Practical regression and Anova using R, 212p. Available from 〈http://cran.r-project.org/doc/contrib/Faraway-PRA.pdf

FDEP, 1994. Approach to the assessment of sediment quality in Florida coastal waters. Vol. 1 Development and evaluation of sediment quality assessment guidelines. Prepared for Florida Department of Environmental Protection, Office of Water Policy, Tallahasee, FL, by MacDonald Environmental Sciences Ltd., Ladysmith, British Columbia.

Fernandes, M.E.B., Carvalho, M.L., 2007. Bioecologia de Ucides cordatus Linnaeus, 1763 (Decapoda: Brachyura) na costa do Estado do Amapá. Bol. Lab. Hidrobiol. 20, 14-21.

Fiscarelli, A.G., Pinheiro, M.A.A., 2002. Perfil sócio-econômico e conhecimento etnobiológico do catador do caranguejo-uçá, Ucides cordatus (Linnaeus, 1763), nos

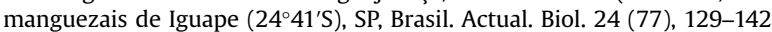

Fishelson, L., Bresler, V., Manelis, R., Zuk-Rimon, Z., Dotan, A., Hornung, H., Yawetz A., 1999. Toxicological aspects associated with the ecology of Donax trunculus (Bivalvia, Mollusca) in a polluted environment. Sci. Total Environ. 226, 121-131.

Fossi, M.C., Casini, S., Savelli, C., Corbelli, C., Franchi, E., Mattei, N., Sanchez-Hernandez, J.C., Corsi, I., Bamber, S., Depledge, H.M., 2000. Biomarker responses at different levels of biological organization in crabs (Carcinus aestuarii) experimentally exposed to benzo)[a]pyrene. Chemosphere 40, 861-874.

Gamfeldt, L., Lefcheck, J.S., Byrnes, J.E.K., Cardinale, B.J., Duffy, J.M., Griffin, J.N., 2015 Marine biodiversity and ecosystem functioning: what's known and what's next? Oikos 124, 252-265. http://dx.doi.org/10.1111/oik.01549.

Goes, P., Branco, J.O., Pinheiro, M.A.A., Barbieri, E., Costa, D., Fernandes, L.L., 2010 Bioecology of the uçá-crab, Ucides Cordatus (Linnaeus, 1763), in Vitória Bay, Espírito Santo State, Brazil. Braz. J. Oceanogr. 58 (2), 153-163.

Gouveia, S.C.R., 2012. Praias arenosas oceânicas do estado de São Paulo (Brasil): síntese dos conhecimentos sobre morfodinâmica, sedimentologia, transporte costeiro e erosão costeira. Revista do Departamento de Geografia, 307-371.

Hagger, J.A., Lowe, D., Dissanayake, A., Jones, M.B., Galloway, T.S., 2010. The inffluence of seasonality on biomarker responses in Mytilus edulis. Ecotoxicology 19 (5), 953-962.

Harford, A.J., Hogan, A.C., Jones, D.R., Dam, R.A.V., 2015. Ecotoxicology of highly treated mine waters: lessons from an Australian Mine. Mine Water Environ. 34 (1), 75-86.

Hose, J.E., Martin, G.G., Gerard, A.S., 1990. A decapod hemocyte classification scheme integrating morphology, cytochemistry, and function. Biol. Bull. 178, $33-45$.

Husson, F., Josse, J., Le, S., Mazet, J., 2012. FactoMineR: Multivariate Exploratory Data Analysis and Data Mining with R. R package version 1.18. http://CRAN.Rproject. org/package=FactoMineR.

Ibge Brasil, 2000. Instituto Brasileiro de geografia e Estatística. Censo Demográfico 2000. Disponível em: 〈http://www.ibge.gov.br〉, (acessed 27.01.16).

Ibge Brasil, 2010. Instituto Brasileiro de geografia e Estatística. Censo Demográfico 2010. Disponível em: 〈http://www.ibge.gov.br $\rangle$, (acessed 27.01.16).

Ibge Brasil, 2012. Instituto Brasileiro de geografia e Estatística. Censo Demográfico 2012. Disponível em: 〈http://www.ibge.gov.br〉, (acessed 27.01.16).

Ihaka, R., Gentleman, R., 1996. R: a language for data analysis and graphics. J. Comput. Graph. Stat. 5 (3), 299-314.

ISA - Instituto Socioambiental, 1998. Diagnóstico socioambiental do Vale do Ribeira. João Paulo Capobianco (Coord.). ISA, São Paulo.

Jergentza, S., Pessacq, P., Mugni, H., Bonetto, C., Schulz, R., 2004. Linking in situ bioassays and population dynamics of macroinvertebrates to assess agricultural contamination in streams of the Argentine pampa. Ecotoxicol. Environ. Saf. 59 (2), 133-141.

Kandroo, M., Tripathi, N.K., Sharma, I., 2015. Detection of micronuclei in gill cells and haemocytes of fresh water snails exposed to mercuric chloride. Int. J. Recent Sci. Res. 6 (8), 5725-5730.

Kaufman, L., Rousseeuw, P.J., 1990. Finding groups in data: an introduction to cluster analysis. Wiley, New York, 283p.

Kirschbaum, A.A., Seriani, R., Pereira, C.D., Assunção, A., Abessa, D.M.D.S., Rotundo, M.M., Ranzani-Paiva, M.J., 2009. Cytogenotoxicity biomarkers in fat snook Centropomus parallelus from Cananéia and São Vicente estuaries, SP, Brazil. Genet. Mol. Biol. 32 (1), 151-154.

Klobučar, G.I.G., Malev, O., Šrut, M., Štambuk, A., Lorenzon, S., Cvetković, Z., Ferrero, E.A., Maguire, I., 2012. Genotoxicity monitoring of freshwater environments using caged crayfish (Astacus leptodactylus). Chemosphere 87 (1), 62-67.

Krebs, C.T., Burns, K., 1977. Long-term effects of an oil spill on populations of the salt-marsh crab Uca pugnax. Science 197 (4302), 484-487.

Krebs, C.T., Valiela, I., 1974. Long-term effects of an oil spill on populations of the salt-marsh crab Uca pugnax. Mar. Pollut. Bull. 5 (9), 140-142.

Lacher, T.E., Goldstein, M.I., 1997. Tropical ecotoxicology: status and needs. Environ. Toxicol. Chem. 16 (1), 100-111.

Lima-Junior, S.E., Cardone, I.B., Goitein, R., 2002. Determination of a method for calculation of allometric condition factor of fish. Acta Sci. 24, 397-400.

Lowe, D.M., Valentino, U.F., Depledge, M.H., 1995. Contaminant-induced lysosoma membrane damage in blood cells of mussels Mytilus galloprovincialis from the Venice Lagoon: an in vitro study. Marine Ecology Progress Series 129, 189-196.

Mahiques, M.M., Burone, L., Figueira, R.C.L., Lavenérer-Wanderley, A.A.O., Capellari, B., Rogacheski, C.E., Barroso, C.P., Santos, L.A.S., Cordero, L.M., Cussioli, M.C., 2009. Anhropogenic influences in a lagoonal environment: a multiproxy approach at the Vaelo Grande Mouth, Cananéia-Iguape System (SE BRAZIL). Braz. J. Oceanogr. 57 (4), 325-337.

Mahiques, M., Figueira, R., Salaroli, A., Alves, D., Gonçalves, C., 2013. 150 years of anthropogenic metal input in a biosphere reserve: the case study of the Cananéia-Iguape coastal system, southeastern Brazil. Environ. Earth Sci. 4 (68), 1073-1087.

Marques, J.P., Guimarães, C.R., Boas, A.V., Carnaúba, P.U., Moraes, J., 2012. Contamination of public parks and squares from Guarulhos (São Paulo State, Brazil) by Toxocara spp. and Ancylostoma spp. Rev. Inst. Med. Trop. São Paulo 54 (5), 267-271.

Marques, O.A.V., Duleba, W., 2004. Estação Ecológica Juréia-Itatins - Ambiente Físico, Flora e Fauna. Holos, Editora Ltda-ME, Ribeirão Preto, SP, 384p.

Martinez, C.B.R., Alvares, E.P., Harris, R.R., Santos, M.C.F., 1999. A morphological study on posterior gills of the mangrove crab Ucides cordatus. Tissue Cell 31 (3) 380-389.

Martins, C.C., Bícego, M.C., Mahiques, M.M., Figueira, R.C., Tessler, M.G., Montone, R. C., 2011. Polycyclic aromatic hydrocarbons (PAHs) in a large South American industrial coastal area (Santos Estuary, Southeastern Brazil): sources and depositional history. Mar. Pollut. Bull. 63 (5), 452-458.

Matozzo, V., Marin, M.G., 2010. First cytochemical study of haemocytes from the crab Carcinus aestuarii (Crustacea, Decapoda). Eur. J. Histochem. 54, 44-49.

Mendonça, J.T., Miranda, L.V. de, 2008. Estatística pesqueira do litoral sul do estado de São Paulo: subsídios para gestão compartilhada. Pan-Am. J. Aquat. Sci. 3 (3), 152-173.

Monserrat, J.M., Martínez, P.E., Geracitano, L.A., Amado, L.L., Martins, C.M.G., Pinho, G.L.L., Chaves, I.S., Ferreira-Cravo, M., Ventura-Lima, J., Bianchini, A., 2007. Pollution biomarkers in estuarine animals: critical review and new perspectives. Comp. Biochem. Physiol. 146, 221-234.

Moore, M.N., Allen, J.I., Mcveigh, A., 2006. Environmental prognostics: an integrated model supporting lysosomal stress responses as predictive biomarkers of animal health status. Mar. Environ. Res. 61, 278-304.

Neri, M., Fucic, A., Knudsen, L.E., Lando, C., Merlo, F., Bonassi, S., 2003. Micronucle frequency in children exposed to environmental mutagens: a review. Mutation Research 544, 243-254.

Newman, M.C., 2013. Bioaccumation. In: NEWMAN, M.C. (Ed.), Quantitative Ecotoxicology. CRC Press/Taylor \& Francis Group, United States, p. 570.

Nudi, A.H., Wagener, A.L.R., Francioni, E., Sette, C.B., Sartori, A.V., Scofield, A.L., 2010 Biomarkers of PAH exposure in crabs Ucides cordatus: laboratory assay and field study. Environ. Res. 110, 137-145.

Nunes, M., 2003. Do passado ao futuro dos moradores tradicionais da Estação Ecológica Juréia-Itatins/SP. Doctoral dissertation. Universidade de São Paulo.

Ospar Commission, 2013. Background document and technical annexes for biological effects monitoring, Monitoring and Assessment Series, Update 2013, OSPAR Commission: London, U.K.

Otomo, P.V., Reinecke, S.A., 2010. Increased cytotoxic and genotoxic tolerance of Eisenia fetida (Oligochaeta) to cadmium after long-term exposure. Ecotoxicology $19,362-368$.

Pauly, D., 1995. Anecdotes and the shifting baseline syndrome of fisheries. Tree 10 1.

Pereira, C.D.S., Abessa, D.M.S., Choueri, R.B., Almagro-Pastor, V., Augusto, C., Maranho, L.A., Díaz, M., Laura, M., Torres, R.J., Gusso-Choueri, P.K., Almeida, J.E., Cortez, F.S., Mozeto, A.A., Silbiger, H.L.N., Sousa, E.C.P.M., Del Valls, T.A., Bainy, A C.D., 2014. Ecological relevance of Sentinels' biomarker responses: a multi-level approach. Mar. Environ. Res. 96, 118-126.

Pereira, C.D.S., Martín-Díaz, M.L., Catharino, M.G.M., Cesar, A., Choueri, R.B., Taniguchi, S., Abessa, D.M.S., Bícego, M.C., Vasconcellos, M.B.A., Bainy, A.C.D., Sousa, E.C.P.M., Delvalls, T.A., 2012. Chronic contamination assessment integrating biomarkers' responses in transplanted mussels - a seasonal monitoring. Environ. Toxicol. 27, 257-267.

Pereira, C.D.S., Martín-Díaz, M.L., Zanette, J., Augusto, C., Choueri, R.B., Abessa, D.M S., Catharino, M.G.M., Vasconcellos, M.B.A., Bainy, A.C.D., Sousa, Moreira, E.C.P., 
Del Valls, J.H., 2011. Integrated biomarker responses as environmental status descriptors of a coastal zone (São Paulo, Brazil). Ecotoxicol. Environ. Saf. 74, 1257-1264.

Peters, E.C., Gassman, N.J., Firman, J.C., Richmond, R.H., Power, E.A., 1997. Ecotoxicology of tropical marine ecosystems. Environ. Toxicol. Chem. 16 (1), 12-40.

Pinheiro, M.A.A., Almeida, R. 2015. Monitoramento da densidade e da estrutura populacional do caranguejo-uçá, Ucides cordatus (Linnaeus, 1763) (Brachyura: Ucididae), Cap. 10,122-133p. In: Turra, A., Denadai, M.R. Protocolos para o Monitoramento de Habitats Bentônicos Costeiros - Rede de Monitoramento de Habitats Bentônicos Costeiros - ReBentos. ISBN (e-book): 978-85-98729-25-1. São Paulo: Instituto Oceanográfico da Universidade de São Paulo, 258p.

Pinheiro, M.A.A., Fiscarelli, A.G. 2001. Manual de Apoio à Fiscalização do Caranguejo-Uçá (Ucides cordatus). Instituto Brasileiro do Meio Ambiente (IBAMA)/ Centro de Pesquisa e Gestão de Recursos Pesqueiros do Litoral Sudeste e Sul (CEPSUL), (1)a Edição, ISBN 85-88570-02-5, Itajaí, 43p.

Pinheiro, M.A.A., Oliveira, A.J.F.C., Fontes, R.F.C., 2008. Introdução ao panorama ambiental da Baixada Santista, Cap. 01, 1-4. In: Oliveira, A.J.F.C., Pinheiro, M.A A., Fontes, R.F.C. (Orgs.). Panorama ambiental da Baixada Santista. Universidade Estadual Paulista - Campus Experimental do Litoral Paulista, 1ª Edição, ISBN 978-85-61498-02-3, São Vicente, SP, 127p.

Pinheiro, M.A.A., Silva, P.P.G., Duarte, L.F.A., Almeida, A.A., Zanoto, F.F., 2012. Accumulation of six metals in the mangrove crab Ucides cordatus (Crustacea: Ucididae) and its food source, the red mangrove Rhizophora mangle (Angiosperma: Rhizophoraceae). Ecotoxicol. Environ. Saf. 81, 114-121.

Pinheiro, M.A.A., Duarte, L.F.A., Toledo, T.R., Adams, M.A., Torres, R.A., 2013. Habitat monitoring and genotoxicity in Ucides cordatus (Crustacea: Ucididae), as tools to manage a mangrove reserve in southeastern Brazil. Environ. Monit. Assess. 185 (10), 8273-8285. http://dx.doi.org/10.1007/s10661-013-3172-9.

Pinheiro, M.A.A., Toledo, T.R., 2010. Malformation in the crab Ucides cordatus (Linnaeus, 1763) (Crustacea, Brachyura, Ocypodidae), in São Vicente (SP), Brazil. Rev. CEPSUL - Biodivers. Conserv. Mar. 1 (1), 1-5

Pinheiro, M.A.A., Fiscarelli, A.G., 2009. Length-weight relationship of the carapace and condition factor of the mangrove crab Ucides cordatus (Linnaeus, 1763) (Crustacea, Brachyura, Ucididae). Braz. Arch. Biol. Technol. 52 (2), 397-406.

Rainbow, P.S., 1997. Ecophysiology of trace metal uptake in crustaceans. Estuar. Coast. Shelf Sci. 44, 169-175.

Rainbow, P.S., 2007. Trace metal bioaccumulation: models, metabolic availability and toxicity. Environ. Int. 33, 576-582.

Rainbow, P.S., BLACK, W.H., 2005. Cadmium, zinc and uptake of calcium by two crabs, Carcinus maenas and eriocheir sinensis. Aquat. Toxicol. 72, 45-65.

Reigada, C.S., Luchini, L.C., Barbieri, E., 2014. Presença de organoclorados em amostras de água e ostras Crassostrea sp. do Município de Cananeia-SP. O Mundo da Saúde 38 (1), 66-74.

Rocha, A.J.S., Santos, T.C.A., Gomes, V., Bícego, M.C., Barbosa, A.C.R.A., Passos, M.J.A. C.R., Hasue, F.M., Ngan, P.V., 2012. Assessment of trophic transfer of benzo(a) pyrene genotoxicity from the post-larval pink shrimp $F$. brasiliensis to the juvenile Florida pompano T. carolinus. Environ. Toxicol. Pharmacol. 34 (3), 969-976.

Sacchi, A., Mouneyrac, C., Bolognesi, C., Sciutto, A., Roggieri, P., Fusi, M., Beone, G.M. Capri, E., 2013. Biomonitoring study of an estuarine coastal ecosystem, the Sacca di Goro lagoon, using Ruditapes philippinarum (Mollusca: Bivalvia). Environ. Pollut. 177, 82-89.

Sant'anna, B.S., Santos, D.M., Marchi, M.R.R.D., Zara, F.J., Turra, A., 2014. Surfacesediment and hermit-crab contamination by butyltins in southeastern Atlantic estuaries after ban of TBT-based antifouling paints. Environ. Sci. Pollut. Res. 21 (10), 6516-6524

Scarpato, R., Migliore, L., Alfinito-Cognetti, G., Barale, R., 1990. Induction of micronucleus in gill tissue of Mytillus galloprovincialis exposed to polluted marine waters. Mar. Pollut. Bull. 21 (2), 74-80.
Schaeffer-Novelli, Y., Cintrón, G., 1986. Guia para estudo de áreas de manguezal: Estrutura, Função e Flora. Caribbean Ecological Research, São Paulo, p. 150.

Semensatto-Jr, D.L., Araújo, G.C.L., Funo, R.H.F., Santa-Cruz, J.O.A.N.A., Dias-Brito, D.I. M.A.S., 2007. Metais e não-metais em sedimentos de um manguezal não-poluído, Ilha do Cardoso, Cananéia (SP). Rev. Pesqui. Geociênc. 34 (2), 25-31.

Seriani, R., Abessa, D.M.D.S., Pereira, C.D., Kirschbaum, A.A., Assunção, A., RanzaniPaiva, M.J.T., 2013. Influence of seasonality and pollution on the hematological parameters of the estuarine fish Centropomus parallelus. Braz. J. Oceanogr. 61 (2), 105-111.

Silva, W.L., Matos, R.H.R., Kristosch, G.C., 2002. Geoquímica e índice de geoacumulação de mercúrio em sedimentos de superfície do estuário de Santos Cubatão (SP). Quim. Nova 25 (5), 753-756.

Sponchiado, G., Reynaldo, E.M.F.L., Andrade, A.C.B., Vasconcelos, E.C., Adam, M.L., Oliveira, C.M.R., 2011. Genotoxic Effects in erythrocytes of Oreochromis niloticus exposed to nanograms-per-liter concentration of $17 \beta$-Estradiol (E2): an assessment using micronucleus test and comet assay. Water Air Soil. Pollut. 218, 353-360.

Sueitt, A.P.E., Yamada-Ferraz, T.M., Oliveira, A.F., Botta, C.M.R., Fadini, P.S., Nascimento, M.R.L., Faria, B.M., Mozeto, A.A., 2015. Ecotoxicological risks of calcium nitrate exposure to freshwater tropical organisms: laboratory and field experiments. Ecotoxicol. Environ. Saf. 117, 155-163.

Svendsen, C., Spurgeon, D.J., Hankard, P.K., Weeks, J.M., 2004. A review of lysosomal membrane stability measured by neutral red retention: is it a workable earthworm biomarker? Ecotoxicol. Environ. Saf. 57, 20-29.

Terlizzi, A., Scuderi, D., Fraschetti, S., Anderson, M.J., 2005. Quantifying effects of pollution on biodiversity: a case study of highly diverse molluscan assemblages in the Mediterranean. Mar. Biol. 148, 293-305.

Tessler, G.M., Suguio, K., Robilotta, P.R., 1987. Teores de alguns elementos traço metálicos em sedimentos pelíticos da superfície de fundo da região Lagunar Cananéia-Iguape. An. Simpósio sobre Ecossistemas Costa Sul Sudeste Bras. 2 255-263.

Theodore, L., Dupont, R.R., 2012. Environmental Health and Hazard Risk Assessment: Principles and Calculations. ISBN 978-1-43-986887-4. 636p.

Torres, R.J., Cesar, A., Pereira, C.D.S., Choueri, R.B., Abessa, D.M.S., Nascimento, M.R. L., Fadini, P.S., Mozeto, A.A., 2012. Bioaccumulation of polycyclic aromatic hydrocarbons and mercury in oysters (Crassostrea rhizophorae) from Two Brazilian Estuarine Zones. Int. J. Oceanogr., 8. http://dx.doi.org/10.1155/2012/838320.

Toufexia, E., Tsarpali, V., Efthimiou, I., Vidali, M.S., Vlastos, D., Dailianis, S., 2013. Environmental and human risk assessment of landfill leachate: an integrated approach with the use of cytotoxic and genotoxic stress indices in mussel and human cells. J. Hazard. Mater. 260, 593-601.

Tsarpali, V., Dailianis, S., 2012. Investigation of landfill leachate toxic potency: an integrated approach with the use of stress indices in tissues of mussels. Aquat. Toxicol. 124-125, 58-65.

Viana, L.F., Tondato, K.K., Súarez, Y.R., Lima-Junior, S.E., 2014. Influence of environmental integrity on the reproductive biology of Astyanax altiparanae Garutti \& Britski. 2000 in the Ivinhema river basin Acta Sci. Biol. Sci. 36 (2), 165-173. http://dx.doi.org/10.4025/actascibiolsci.v36i2.21052.

Wunderlich, A.C., Pinheiro, M.A.A., Rodrigues, A.M.T., 2008. Biologia do caranguejouçá, Ucides cordatus (Crustacea: Decapoda: Brachyura), na Baía da Babitonga, Santa Catarina, Brasil. Rev. Bras. de. Zool. 25 (2), 188-198.

Wei, K., Yang, J., 2015. Oxidative damage of hepatopancreas induced by pollution depresses humoral immunity response in the freshwater crayfish Procambarus clarkia. Fish. Shellfish Immunol. 43 (2), 510-519.

Yao, C.L., Wu, C.G., Xiang, J.H., Li, F., Wang, Z.Y., Han, X., 2008. The lysosome and lysozyme response in Chinese shrimp Fenneropenaeus chinensis to Vibrio anguillarum and laminarin stimulation. J. Exp. Mar. Biol. Ecol. 363, 124-129.

Zar, J.H., 1999. Biostatistical Analysis, 4th ed. Prentice Hall, United States, p. 663. 